\title{
Double Track System bagi Pelaku Tindak Pidana \\ Berlatar Belakang Homoseksualitas \\ (Gagasan dalam Pembaruan Hukum Pidana)
}

\section{Double Track System for Criminals Against Homosexuality Background (Ideas in Criminal Law Reform)}

\author{
Yaris Adhial Fajrin, Ach. Faisol Triwijaya, dan Moh. Aziz Ma'ruf \\ Dosen Fakultas Hukum Universitas Muhammadiyah Malang, Mahasiswa Magister Ilmu Hukum \\ Universitas Brawijaya Malang, dan Mahasiswa Ilmu Hukum \\ Universitas Muhammadiyah Malang \\ Email: yaris@umm.ac.id
}

Naskah diterima: 17 April 2020

Naskah direvisi: 28 September 2020

Naskah diterbitkan: 1 November 2020

\begin{abstract}
Homosexuality is seen as deviant behavior and often becomes the background of a crime. Punishing a criminal offender who has a homosexual background does not automatically solve a crime. Crime punishment actually has a negative impact on criminal offenders, such as stigmatization and obstruction of any efforts to restore the criminal's sexual orientation. The purpose of punishment in criminal law reform is to improve criminal offenders into better individuals. Based on this background, the "double track system" becomes a relevant idea to be developed, especially now that Indonesia is in the era of reforming the national criminal law. The issues raised were the position of homosexuality in criminal law and the idea of a double track system against the criminal with a homosexual background. The legal research method used is normative research method. The results show that homosexuality is not a criminal offense under Indonesia's positive criminal law; it is just that homosexuality can be the cause of a crime. The criminal offenders can be given a sanction of action, given that psychology recognizes that there are various therapies to restore sexual orientation. The idea of a double track system is a reflection of the reform of national criminal law which is oriented towards balance values. These values can be used as a basis for immediate implementation of a double track system legislative policy for criminal offenders with a homosexual background in Indonesia's criminal system.
\end{abstract}

Keywords: homosexuality; Double Track System; criminal law reform

\begin{abstract}
Abstrak
Homoseksualitas dipandang sebagai penyimpangan perilaku, tidak sedikit homoseksual menjadi latar belakang terjadinya suatu tindak pidana. Menjatuhkan pidana terhadap pelaku tindak pidana yang memiliki latar belakang homoseksualitas, tidak serta merta menjadi solusi penyelesaian suatu kejahatan. Pidana justru memberikan dampak negatif terhadap pelaku, seperti stigmatisasi dan terhambatnya upaya mengembalikan orientasi seksual pelaku. Tujuan pemidanaan dalam pembaruan hukum pidana adalah memperbaiki pelaku menjadi individu yang lebih baik. Berdasarkan latar belakang tersebut, "double track system" menjadi gagasan yang relevan untuk diupayakan, terlebih saat ini Indonesia sedang berada pada periode pembaruan hukum pidana nasional. Permasalahan yang diangkat yakni kedudukan homoseksualitas dalam hukum pidana dan gagasan double track system terhadap pelaku tindak pidana berlatarbelakang homoseksualitas. Metode penelitian hukum yang digunakan adalah metode penelitian normatif. Hasil yang didapat bahwa homoseksualitas bukan merupakan tindak pidana menurut hukum pidana positif Indonesia, hanya saja homoseksualitas dapat menjadi penyebab terjadinya tindak pidana. Pelaku tindak pidana tersebut dapat diberikan sanksi tindakan, mengingat
\end{abstract}


dalam ilmu kejiwaan mengenal adanya berbagai terapi pengembalian orientasi seksual. Ide double track system merupakan cerminan pembaruan hukum pidana nasional yang berorientasi kepada nilainilai keseimbangan. Manfaat tersebut dapat dijadikan pijakan untuk segera melakukan kebijakan legislasi double track system bagi pelaku tindak pidana yang berlatarbelakang homoseksual dalam sistem pemidanaan di Indonesia.

Kata kunci: homoseksualitas; Double

Track System; pembaharuan hukum pidana

\section{Pendahuluan}

Perkembangan zaman hingga mencapai era globalisasi saat ini, turut menggeser nilai-nilai peradaban manusia, yang pada akhirnya berimplikasi terhadap pola perilaku antar sesama manusia dalam kehidupan bermasyarakat. Perubahan dan pergesaran tersebut dipengaruhi oleh perubahan cara pandang dan maindset masyarakat suatu bangsa. Cara pandang masyarakat yang sebelumnya tradisional berubah ke arah modern, lebih banyak dipengaruhi oleh pemikiran barat (western). ${ }^{1}$ Pola hidup masyarakat modern yang cenderung mengarah ke pandangan liberalism ditangkap sebagai suatu filosofi kebebasan yang tak terbatas oleh sebagian penduduk suatu bangsa. Kebebasan tersebut merupakan cerminan dari eksistensi indetermisme yang dikemukakan Descartes, ${ }^{2}$ yang sedikit banyak

Masyarakat Barat sendiri (termasuk Amerika Serikat) menjadi semakin maju sebagai akibat dari industrialisasi dan urbanisasi yang pesat. Sejarawan telah menjelaskan bahwa pertumbuhan ekonomi konsumen kapitalis mendorong etos sosial baru yang memotivasi orang untuk memandang tubuh manusia sebagai sumber kepuasan seksual, bukan hanya sebagai sumber reproduksi. Dalam lingkungan ini, keragaman preferensi dan perilaku seksual yang lebih besar, termasuk homoseksualitas, menjadi lebih terlihat di depan umum. Lihat: Jordan Blair Woods, "LGBT Identity and Crime", California Law Review, Vol. 105, No. 3, 2017. hal. 667-734.

Syahrul Fauzul Kabir, "Kejahatan dan Hukuman: Tantangan Filosofis Determinisme-Kausal Terhadap Pertanggungjawaban Pidana", Jurnal Hukum E̊ Pembangunan, Vol. 49, No. 2, 2019, hal. 279-298. memberikan dampak negatif terhadap perilakuperilaku masyarakat yang cenderung mengarah kepada kebebasan yang tidak terbatas.

Indonesia sebagai bagian dari masyarakat dunia, tidak dapat lepas dari dampak perubahan dan perkembangan zaman, baik yang bernilai positif maupun negatif. Pemahaman yang kurang tepat mengenai liberalism atau kebebasan, memunculkan berbagai perilaku negatif yang tidak sedikit mengarah pada penyimpangan perilaku, ${ }^{3}$ seperti seks bebas, kenakalan remaja, pornografi, narkotika, dan homoseksual. ${ }^{4}$ Penyimpangan perilaku menurut Topo Santoso merupakan perbuatan yang menimbulkan kerugian atau keparahan sosial (social injuries). ${ }^{5}$ Munculnya berbagai penyimpangan perilaku tersebut mengindikasikan mulai tergerusnya nilai-nilai ideologi suatu bangsa, dalam hal ini adalah ideologi Pancasila sebagai landasaan idiil bangsa Indonesia, sebagaiakibat berkembangnya budaya liberal yang kontradiktif dengan nilainilai komunitarian masyarakat Indonesia. ${ }^{6}$ Bahkan tidak jarang penyimpangan perilaku tersebut telah meresahkan dan mendatangkan kerugian bagi masyarakat, atau bahkan bagi negara sebagai organisasi terbesar masyarakat.

Penyimpangan perilaku dapat mendatangkan kerugian bagi orang secara personal ataupun masyarakat secara komunal,

Alfred Kinsey merilis penelitian inovatif yang menunjukkan bahwa tidak jarang pria dan wanita terlibat dalam tindakan seks ilegal di beberapa titik kehidupan mereka, termasuk perzinahan, percabulan, sodomi, dan homoseksualitas. Lihat: Jordan Blair Woods, "LGBT Identity and Crime"... hal. 697

4 Beberapa ahli teori proses sosial berpandangan bahwa homoseksual disebut sebagai penyimpangan seksual karena masyarakat memberi label atau cap seperti itu. Ibid. 693.

Topo Santoso dan Eva Achjani Zulfa, Kriminologi, Jakarta: Rajawali Press, 2014, hal 17. Sedangkan Palus Hadisuprapto mengemukakan perilaku menyimpang sebagai perbuatan yang secara konvensional dianggap tidak sesuai dengan kepatutan. Lihat juga: Paulus Hadisuprapto, "Studi Tentang Makna Penyimpangan Perilaku di Kalangan Remaja”, Jurnal Kriminologi Indonesia, Vol. 3, No. III, September 2004, hal. 9-18.

6 Kurniawan Kunto Yuliarso dan Nunung Prajarto, "Hak Asasi Manusia (HAM) di Indonesia: Menuju Democratic Governance", Jurnal Ilmu Sosial \& llmu Politik, Vol. 8, No. 3, Maret 2005, hal. 291-308. 
sehingga hal tersebut dikategorikan sebagai kejahatan. Kejahatan, secara sosiologis, merupakan salah satu jenis gejala sosial dalam interaksi yang terbangun antar manusia. ${ }^{7}$ Demikian pula dengan hukum pidana merupakan bidang hukum yang penuh dengan dimensi sarat nilai seperti ajaran etika, moral. Hukum pidana tidak bisa dilepaskan dari dimensi moralitas suatu masyarakat, sebab kejahatan dianggap a-sosial karena masyarakat menghendakinya (mala per se). ${ }^{8}$ Korelasi antara hukum, pidana, dan moralitas tersirat dalam ketentuan Pasal 18B dan pasal 28E UUD 1945 (sebagai landasan konstitusional yang secara hierarki berada di bawah dan terkorelasi dengan Pancasila sebagai landasai idiil dan moralitas bangsa Indonesia), yang menyatakan Indonesia sebagai negara hukum. Atas dasar itu pula lah maka hanya bagi kejahatan yang ditetapkan oleh peraturan perundang-undangan sebagai tindak pidana saja lah yang dapat ditindak oleh hukum pidana positif Indonesia (asas legalitas).

Penyimpangan perilaku sebagaimana tersebut di atas, tidak sedikit yang telah dikategorikan sebagai bagian dari tindak pidana, baik itu di dalam Kitab Undangundang Hukum Pidana (KUHP) maupun yang tersebar di berbagai undang-undang di luar KUHP. Khusus mengenai keterkaitan antara homoseksualitas dan kejahatan, ${ }^{9}$ menarik untuk ditelaah dalam tulisan ini, mengingat dewasa ini ada berbagai tindak pidana yang

\footnotetext{
Hardianto Djanggih dan Nurul Qamar, "Penerapan TeoriTeori Kriminologi dalam Penanggulangan Kejahatan Siber (Cyber Crime)", Pandecta, Vol. 13, No. 1, Juni 2018, hal. 11

8 Lidya Suryani Widayati, "Kebijakan Kriminalisasi Kesusilaan dalam Rancangan Undang-undang tentang Hukum Pidana dari Perspektif Moral", Negara Hukum, Vol.9, No.2, November 2018. hal. 181-198.

9 Menurut Foucault, pandangan homoseksualitas sebagai perilaku yang menyimpang baru muncul di akhir abad ke-19 dan awal abad ke-20. Sebelumnya, homoseksual merupakan tindakan kriminal yang melanggar hukum dan harus mendapatkan sanksi. Lihat juga Sana Loue, "Case Studies in Society, Religion, And Bioethics", Cham: Springer, 2020. hal. 13. Menurut sejarawan Jonathan Katz, kata "heteroseksual" dan "homoseksual" bahkan tidak ada di Amerika Serikat sampai tahun 1892. Lihat juga: Jordan Blair Woods, "LGBT Identity and Crime”..., hal. 693.
}

terjadi di Indonesia dilakukan atas dasar motif atau latar belakang persoalan homoseksualitas pelaku. Sebut saja kasus pembunuhuan berantai yang dilakukan oleh "Ryan Jombang". Ada pula beberapa kasus pembunuhan yang terjadi di berbagai daerah di Indonesia yang berlatar belakang homoseksualitas, ${ }^{10}$ dan yang paling menyedot perhatian publik Indonesia dan Inggris adalah kasus pemerkosaan dan kekerasan seksual terhadap 48 (empat puluh delapan) laki-laki yang dilakukan oleh mahasiswa Indonesia bernama Reynhard Sinaga di Manchester, Inggris. ${ }^{11}$ Beberapa penelitian juga menunjukkan bahwa homoseksualitas cenderung menjadi faktor pendorong untuk melakukan penyalahgunaan alkohol, narkotika maupun obat-obatan terlarang lainnya. ${ }^{12}$

Tahun 1980, "American Psychiatric Association" melalui DSM-III (Diagnostic and Statistical Manual of Mental Disorder, Third Edition) menempatkan homoseksual sebagai kelainan seksual tetapi bukan merupakan gangguan kepribadian. ${ }^{13}$ Hal tersebut berimplikasi yuridis, khususnya dalam hal pidana dan pemidanaan para pelaku yang memiliki latar belakang homoseksualitas. Kedudukan homoseksualitas yang bukan merupakan gangguan kepribadian, menjadikan para pelaku

Edy Gune, 22 Februari2016, "Astaga, 25 Kasus Pembunuhan ini Berlatar Nafsu Sejenis” https:/www.kompasiana.com/ edygune/56cadd1d317a61160f49154e/astaga-25-kasuspembunuhan-ini-berlatar-nafsu-sejenis?page $=$ all. diakses tanggal 16 April 2020.

11 Endang Nurdin dan Muhamad Susilo, 11 Januari 2020, "Reynhard Sinaga: Bagaimana Kejahatannya Terbongkat, Mengapa Pengadilan "Dirahasiakan" dan Semua yang Perlu anda Ketahui", https://www.bbc.com/indonesia/ dunia-51060249. diakses tanggal 28 September 2020.

12 Diantaranya adalah penelitian dari Charles E. Smith tahun 1954 yang mencoba memahami mengenai hubungan antara identitas gay dan kriminalitas dengan membandingkan 100 tahanan gay dengan rekan nongay, dan menemukan bahwa pelanggaran paling umum yang dilakukan oleh laki-laki gay adalah sodomi. Ada pula penelitian dari Peter Keogh (2009), Julie Fish (2012), dan Institute of Alcohol Studies (2013). Lihat: Charlotte Knight and Kath Wilson, Lesbian, Gay, Bisexual and Transpeople (LGBT) and the Criminal Justice System, London: Palgrave Macmillan, 2016, hal. 95-97.

13 Peter Conrad and Alison Angell, "Homosexuality and Remedicalization", Society, Vol. 41, No. 5, 2004, hal 33 34. 
kejahatan berlatar belakang homoseksualitas dapat dimintai pertanggungjawaban secara pidana (dapat dipidana sebagaimana orang pada umumnya). ${ }^{14}$ Herbert L. Packer mengingatkan mengenai kedudukan hukum pidana sebagai pengancam utama (primer threatener) ${ }^{15}$, sehingga dalam hal penjatuhan pidana harus cermat dan hati-hati. Terlebih lagi penjatuhan sanksi pidana bagi pelaku kejahatan yang memiliki latar belakang homoseksualitas, sebab pidana dan pemidanaan dapat memberikan label/cap ${ }^{16}$ yang dapat menghambat proses rehabilitasi maupun resosialisasi dikemudian hari. Selain itu, mengingat kenyataan mengenai ketimpangan antara kapasitas dengan jumlah penghuni lembaga pemasyarakatan yang over capacity, yang justru mendorong seseorang memiliki kelainan orientasi seksual. ${ }^{17}$ Dapat dibayangkan jika seorang gay menjalani hukuman di penjara yang seluruh lingkungannya adalah laki-laki, atau seorang lesbian yang menjalani hukuman di penjara yang seluruh lingkungannya adalah perempuan. Hal tersebut justru akan memberikan akibat negatif, seperti penularan perilaku menyimpang seksual kepada narapidana lainnya, hingga penularan penyakit seksual.

Mendasarkan kepada penjabaran latar belakang di atas penulis mengangkat dua permasalahan dalam tulisan ini yaitu:

14 Sebab sanksi pidana dikenakan kepada orang yang normal jiwanya, orang yang mampu bertanggung jawab. Lihat: Dwidja Priyatno, Sistem Pelaksanaan Pidana Penjara di Indonesia, Bandung: PT Refika Aditama, 2006, hal 10.

15 Packer menjelaskan bahwa hukum pidana akan berorientasi dan bermuara pada sanksi pidana, di mana ia (hukum pidana, pen.) merupakan penjamin yang utama/terbaik (primer guarantor) dan sekaligus sebagai pengancam yang utama (primer threatener), atau dapat pula merupakan sarana terbaik dalam menghadapi kejahatan. Lihat: Lilik Mulyadi. "Eksistensi Hukum Pidana Adat di Indonesia: Pengkajian Asas, Norma, Teori, Praktik dan Prosedurnya", Jurnal Hukum dan Peradilan Vol. 2, No. 2, 2013, hal. 225-246.

16 Yesmil Anwar dan Adang, Pembaruan Hukum Pidana, Reformasi Hukum, Jakarta: Penerbit PT Grasindo, 2008, hal. 141.

17 Irnanda, 25 Juli 2019 "Terpaksa Menjadi Gay di Balik Jeruji Besi” https://news.detik.com/video/190725027/terpaksamenjadi-gay-di-balik-jeruji-besi, diakses tanggal 28 Maret 2020.
1. Bagaimana kedudukan homoseksualitas dalam hukum pidana positif Indonesia?

2. Bagaimana gagasan double track system terhadap pelaku tindak pidana yang dilatarbelakangi oleh perilaku homoseksualitas?

Terdapat beberapa tulisan atau penelitian terdahulu yang memiliki kedekatan dengan tulisan ini, baik itu dalam hal objek kajian maupun dari segi permasalahan yang diangkat. Pertama, artikel ilmiah karya Fatimah Asyari yang berjudul "LGBT dan Hukum Positif Indonesia", ${ }^{18}$ yang menelaah persoalan LGBT dari kaca mata hukum perkawinan dan adminstrasi kependudukan. Kedua, artikel ilmiah karya Lidya Suryani Widayati yang berjudul "Kebijakan Kriminalisasi Kesusilaan dalam Rancangan Undang-undang tentang Hukum Pidana dari Perspektif Moral", ${ }^{19}$ yang menelaah kriminalisasi kejahatan kesusilaan dari perspektif pemidanaan. Berbeda dengan kedua tulisan sebelumnya, tulisan ini lebih menekankan kepada persoalan pidana dan pemidanaan pelaku berlatar belakang homoseksualitas, dengan menggunakan perspektif pembaruan hukum pidana Indonesia. Tulisan ini dimaksudkan untuk memberikan sumbangsih pemikiran di bidang pembaruan hukum pidana Indonesia, terlebih lagi saat ini Indonesia sedang dalam masa perumusan KUHP dan KUHAP Nasional, yang mengedepankan nilai-nilai humanistik dan Pancasila atau dengan kata lain hukum yang bercorak keindonesiaan.

\section{Metode Penelitian}

Jenis penelitian yang digunakan dalam tulisan ini yaitu yuridis normatif. Pendekatan yang digunakan adalah pendekatan perundangundangan yakni Undang-Undang Dasar Negara Republik Indonesia 1945, Undang-undang Nomor 1 Tahun 1946 tentang Peraturan Hukum Pidana, dan undang-undang terkait lainnya, selain itu

1 Fatimah Asyari, "LGBT Dan Hukum Positif Indonesia", Jurnal Legalitas, Vol. 2, No. 2, Desember 2017, hal. 58.

19 Lidya Suryani Widayati, "Kebijakan Kriminalisasi Kesusilaan dalam Rancangan Undang-undang”..., hal. 181-198. 
guna melengkapi tulisan ini lebih komperhensif maka pendekatan lainnya yang digunakan yaitu pendekatan konseptual, dan perbandingan. Sumber bahan hukum yang digunakan yaitu berasal dari peraturan perundang-undangan dan literatur yang bersinggungan dengan penelitian ini. Teknik analisa yang digunakan yaitu secara kualitatif, dengan menguraikan bahan-bahan hukum yang sudah terkumpul tersebut secara bermutu dalam bentuk kalimat yang teratur, runtun, logis, tidak tumpang tindih, dan efektif sehingga memudahkan dalam hal interpretasinya dan pemahaman hasil analisisnya. Kemudian dari bahan hukum tersebut penulis lakukan analisis dengan penggunaan teori yang relevan dengan penelitian.

\section{Kedudukan Homoseksualitas \\ Hukum Pidana Positif Indonesia}

dalam

\section{A. Perkembangan Homoseksualitas}

Terdapat 2 (dua) pandangan dalam melihat persoalan seksualitas. Pertama, kelompok esensialisme yang memandang bahwa jenis kelamin, orientasi maupun identitas seksual, bersifat bawaan/natural sehingga tidak dapat diubah. ${ }^{20}$ Kedua, kelompok social constructionism yang berpandangan bahwa hal-hal tersebut dapat diubah. ${ }^{21}$ Adanya perbedaan mengenai persoalan seksualitas tersebut, turut memicu perdebatan kedua pandangan tersebut mengenai persoalan homoseksualitas. Hal tersebut dapat dilihat dari sejarah penempatan homoseksual di dalam DSM (Diagnostic and Statistical Manual of Mental Disorder) yang dikeluarkan oleh American Psychiatric Association (APA), yang terus

20 Kelompok ini berpandangan jenis kelamin hanya 2 (dua) jenis, yakni laki-laki dan perempuan. Untuk orientasi seksual hanya heteroseksual, serta mengenai identitas gender akan selaras dengan jenis kelamin (perempuan adalah feminin, dan laki-laki adalah maskulin). Jika terdapat kelompok yang berada di luar mainstream tersebut dipandang sebagai abnormal. Lihat: Ani Khairani, "Pandangan Konselor tentang Homoseksual", Ta'dibuna, Vol. 8, No. 1, 2019, hal. 79-97.

21 Sebagai sebuah konstruksi sosial maka seksualitas bersifat cair, dan merupakan suatu kontinum. Sehingga jenis kelamin tidak hanya terdiri dari laki-laki dan perempuan namun juga interseks dan transgender/transeksual. Begitu juga orientasi seksual, tidak hanya heteroseksual namun juga homoseksual dan biseksual. Ibid. mengalami perubahan. Awalnya homoseksualitas digolongkan sebagai penyakit kejiwaan (mental disorder) dalam DSM-I (sejak tahun 1952-1968). ${ }^{22}$ Dalam DSM-I pun homoseksualitas digolongkan sebagai gangguan mental kepribadian sociopath karena dipandang melanggar norma masyarakat. ${ }^{23}$ Kemudian dalam DSM-II (tahun 1968) homoseksual didefinisikan sebagai patologi medis, sehingga mengkategorikan homoseksualitas di bawah "Gangguan Kepribadian dan Gangguan Non-Psikotik Tertentu", khususnya di bawah "Penyimpangan Seksual" (Homoseksualitas sekarang merupakan gangguan mental resmi, psikopatologi). ${ }^{24}$

Homoseksual didefinisikan sebagai seseorang yang cenderung memilih orang yang sejenis kelamin dengannya sebagai pasangan seksual, ${ }^{25}$ yang dibedakan menjadi gay (lakilaki dengan laki-laki) dan lesbian (perempuan dengan perempuan). ${ }^{26}$ Homoseksual merupakan disorientasi fungsi seksual yang disebabkan faktor psikologis/kejiwaan. ${ }^{27}$ Tokoh yang pertama kali memperkenalkan istilah "homoseksual", yaitu Karl Maria Kerbeny di tahun 1869.28 Ia berpandangan bahwa homoseksualitas merupakan patologi medis karena bawaan sejak lahir (genetik) sehingga tidak dapat diubah. ${ }^{29}$ Tidak berbeda jauh pula

22 Peter Conrad and Alison Angell, "Homosexuality and Remedicalization"... hal. 33.

23 Gallo Ajeng Yusinta Dewi dan Endang Sri Indrawati, "Pengalaman Menjadi Gay (Studi Fenomenologi Pada Pria Homoseksual Menuju Coming Out)", Jurnal Empati, Vol. 7, No. 3, Agustus 2017, Hal 116-126.

24 Peter Conrad and Alison Angell, "Homosexuality and Remedicalization” ..., hal. 33

25 Sana Loue, "Case Studies in Society, Religion, And Bioethics"..., hal. 21.

26 Terminologi "gay" dan "lesbian" merupakan bagian dari istilah "LGBT" yang biasa digunakan untuk menggambarkan orientasi seksual dan identitas gender selain biseksual dan transgender. Lihat: Jordan Blair Woods, "LGBT Identity and Crime" ..., hal. 678.

27 Kelly Brook, Education of Sexuality for Teenager, North Carolina: Charm Press, 2001, hal. 89.

28 Peter Conrad and Alison Angell, "Homosexuality and Remedicalization”... hal 32

29 Homoseksualitas merupakan patologis medis, sehingga tidak tepat diposisikan sebagai tindak pidana. Kriminalisasi terhadap homoseksualitas dipandang tidak adil dan tidak efektif, karena itu bawaan. Ibid. 
dengan Kerbeny, Sigmund Freud memandang homoseksualitas sebagai penyimpangan perkembangan seksual yang tidak dapat diubah ketika telah dewasa, tetapi masih bisa diubah ketika seseorang masih di usia anak-anak. ${ }^{30}$ Tetapi pandangan mengenai tidak dapat diubah/diobatinya homoseksualitas dalam diri seseorang, mendapatkan bantahan dari pakarpakar psikologi lainnya, diantaranya adalah 3 (tiga) orang psikolog (yang juga pengikut ajaran psikoanalitik Freud), yaitu Edmund Bergler, Irving Bieber, dan Charles Socarides, yang menyakini bahwa homoseksualitas sebagai penyakit mental yang berasal dari "pra Oedipal" (sebelum dewasa) dapat diubah menjadi heteroseksual melalui pengobatan psychoanalytic. $^{31}$

Perbedaan pandangan dari berbagai pakar tersebut, turut memicu dan mendorong wacana untuk mengeluarkan homoseksualitas dari daftar DSM. Hingga pada akhirnya pada tahun 1973 homoseksual benar-benar dikeluarkan dari daftar DSM (di dalam DSM3). Keputusan tersebut mendapatkan kritikan dan pertentangan dari berbagai psikolog, sehingga memunculkan istilah baru yang disebut dengan Ego-dystonic homosexuality (EDH) di dalam DSM-III pada 1980. ${ }^{32}$ Pada tahun 1987, EDH dicabut di dalam DSM-IIIR, sehingga sisa terakhir dari homoseksualitas medis telah dihapus dari manual resmi

30 Freud berpandangan bahwa semua anak pada dasarnya biseksual dan mengalami fase homoseksual selama perkembangan psikoseksual awal, tetapi kebanyakan anak tumbuh dari fase ini sebelum dewasa. Hasrat homoseksual tetap sebagai dorongan tak sadar selama perkembangan psikoseksual dan dibelokkan untuk melayani tujuan lain dalam perilaku terbuka. Lihat: Jordan Blair Woods, "LGBT Identity and Crime" ..., hal. 686. Lebih lanjut Freud berpandangan walau hasrat homoerotik sebagai bagian dari perkembangan anak normal umumnya, hal yang harus ditinggalkan atau "ditekan" untuk perkembangan orang dewasa yang "matang". Lihat: Peter Conrad and Alison Angell, "Homosexuality and Remedicalization" ..., hal. 32 .

31 Ibid. hal. 32-33.

32 EDH dipandang sebagai diagnosis kompromi, di mana mengubah penekanan mengenai homoseksualitas dari "konflik tentang orientasi seksual" menjadi "kemampuan untuk mencapai gairah heteroseksual". Ibid. hal. 33 dan 34. psikiatri. ${ }^{33}$ Hal tersebut kemudian diikuti oleh WHO yang mencabut kata "homoseksualitas" dari International Classification of Diseases (ICD) pada 17 Mei 1990, ${ }^{34}$ dan juga oleh Depkes RI dalam buku "Pedoman Penggolongan dan Diagnosis Gangguan Jiwa di Indonesia" (PPDGJ II) edisi II tahun 1983 dan PPDGJ III tahun 1993, homoseksualitas juga dihapus (dan tidak lagi termasuk) dalam daftar gangguan jiwa dan sudah dicantumkan. ${ }^{35}$ Pada 1994, APA mengeluarkan DSM-IV yang direvisi kembali menjadi DSM-IV TR (text revision) pada 2000, yang seluruhnya sudah tidak ditemukan sama sekali homoseksualitas sebagai kelainan seksual. ${ }^{36}$

Meskipun telah hilang dari daftar DSM, beberapa pakar psikologi masih bersikukuh memandang persoalan homoseksualitas sebagai sesuatu yang dapat disembuhkan atau diubah. Sekelompok kecil psikiater yang vokal terus menawarkan terapi reparatif atau konversi untuk gay dan lesbian. Paling vokal untuk pandangan patologis tentang homoseksualitas adalah sekelompok psikoanalis yang disebut "National Association for Research and Therapy of Homosexuality" (NARTH) yang didirikan pada tahun 1992, dipimpin oleh Charles Socarides dan Joseph Nicolosi. NARTH berpandangan bahwa homoseksualitas merupakan hasil dari perkembangan masa kanak-kanak yang tidak sehat (tidak biologis) sehingga dapat diubah. ${ }^{37}$ Socarides berpendapat bahwa homoseksual bukan merupakan penyakit/kelainan bawaan dari lahir melainkan merupakan wawasan yang

33 Ibid. hal. 34.

34 Charlotte Knight and Kath Wilson, Lesbian, gay, bisexual and trans people (LGBT) and the criminal justice system"..., hal. 92.

35 Ani Khairani, "Pandangan konselor tentang homoseksual" ..., hal. 81.

36 EDH bergeser menjadi "gender identity disorder" (GID) di dalam DSM-III sampai dengan DSM-IV TR. Diagnosis GID ditempatkan di DSM guna memungkinkan pengobatan: (1) transgender dan orang dewasa transeksual, dan (2) anak-anak yang menunjukkan perilaku lintas gender yang meresap dan ketidaknyamanan tentang organ seks mereka. Lihat: Peter Conrad and Alison Angell, "Homosexuality and Remedicalization" ..., hal. 32.

37 Ibid., hal. 34. 
disadari, sehingga homoseksual (termasuk LGBT) merupakan suatu alternatif gaya hidup masyarakat Amerika di tahun 70-an. ${ }^{38}$ Tidak berbeda jauh, Dadang Hawari menjelaskan bahwa homoseksual merupakan perilaku seks menyimpang yang bukan disebabkan oleh faktor gen atau keturunan karena manusia diciptakan dalam kondisi fitrah (suci, bersih tanpa dosa), sehingga homoseksual terjadi karena faktor perkembangan kepribadian yang dipengaruhi oleh lingkungan. ${ }^{39}$

Komunitas homoseksualitas telah ada di Indonesia sudah sejak lama. Berdasarkan penelusuran penulis, di mulai sekitar tahun 1968 muncul istilah "Wadam" (Wanita Adam), yang diikuti dengan pendirian organisasi Wadam pertama yaitu Himpunan Wadam Djakarta (HIWAD) pada tahun 1969 dengan difasilitasi oleh Gubernur Jakarta, Ali Sadikin. Kemudian istilah "Wadam" berubah menjadi Waria (Wanita Pria) pada tahun 1980.40 Pada tanggal 1 Maret 1982, Dede Oetomo, mendirikan organisasi gay pertama di Indonesia, yaitu Lambda Indonesia, yang sekretariatnya bertempat di Solo. ${ }^{41}$ Kemudian diikuti pendirian organisasi formal lesbian di Jakarta dengan sebutan Perlesin (Persatuan Lesbian Indonesia), hal tersebut didasarkan pada catatan Antropolog Belanda bernama Saskia Wieringa. ${ }^{42}$ Pada tahun 1985, sebuah kelompok gay di Yogyakarta mendirikan Persaudaraan

38 Ibid., hal. 32.

39 Ani Khairani dan Didin Saefudin, "Homoseksual Berdasarkan Pandangan Psikologi Islam”, Jurnal Ta'dibuna, Vol. 7, No. 2, 2018, hal. 114-136.

40 Roby Yansyah dan Rahayu, "Globalisasi Lesbian, Gay, Biseksual, dan Transgender (LGBT): Perspektif HAM dan Agama dalam Lingkup Hukum di Indonesia” Jurnal Law Reform, Vol. 14, No. 1, 2018. hal. 132-146.

41 Dede Oetomo dan Tom Boellstorff, Renungan Tentang Hak-hak Seksual, Politik, dan Kajian Seksualitas di Indonesia, dalam Bennett, Linda Rae. et.al (editor) Seksualitas di Indonesia; Politik Seksual, Kesehatan, Keberagaman, dan Representasi, Jakarta: Yayasan Pustaka Obor Indonesia, 2018, hal. 431-432.

42 Evelyn Blackwood. Subjektivitas Lesbian: Butch, Femme, dan Andro Sejak Orde Baru Hingga Era Reformasi di Indonesia, dalam Bennett, Linda Rae. et.al (editor) Seksualitas Di Indonesia; Politik Seksual, Kesehatan, Keberagaman, dan Representasi. Jakarta: Yayasan Pustaka Obor Indonesia, 2018. hal.334-335.
Gay Yogyakarta (PGY). Pada tanggal 1 Agustus 1987, Kelompok Kerja Lesbian dan Gay Nusantara (KKLGN) yang kemudian disingkat menjadi Gay Nusantara (GN) didirikan di Surabaya, sebagai penerus Lambda. ${ }^{43}$ Pada bulan Desember 1993, diadakan Kongres Lesbian \& Gay Indonesia pertama (KLGI) di Kaliurang, di wilayah utara Yogyakarta, kongres tersebut menghasilkan 6 (enam) poin ideologis untuk arah masa depan gerakan gay dan lesbian dalam bahasa Indonesia. ${ }^{44}$

Homoseksual dipandang menyimpang oleh konfigurasi sosial dalam masyarakat Indonesia, yang ditampakkan dari adanya penolakan masyarakat maupun tokok-tokoh agama di Indonesia terhadap kelompok-kelompok homoseksulitas. Hal tersebut dapat dilihat dari hasil kajian yang dilakukan oleh Kementerian Pemberdayaan Perempuan dan Perlindungan Anak Republik Indonesia bekerja sama dengan Pusat Penelitian Kesehatan Universitas Indonesia pada tahun 2015, mengenai pandangan masyarakat terhadap lesbian, gay, biseksual dan transgender (LGBT) di Jakarta, Bogor, Depok dan Tangerang. ${ }^{45}$ Penolakan tersebut hanya terbatas pada perilaku LGBT tetapi tidak mencakup kepada pembatasan hakhak asasi yang mereka miliki sebagai manusia seperti hak untuk beribadah, mendapatkan pendidikan, pekerjaan, dan lain-lain. (kecuali hak untuk untuk menikah sesama jenis yang masih mendapatkan penolakan).

Terkait persoalan kejahatan, seseorang yang memiliki penyimpangan berbentuk homoseksual memiliki kecenderungan berperilaku kriminal, sebagaimana pendapat Magda Bhinetty. Menurut Psikolog Universitas Gadjah Mada tersebut, kecenderungan perilaku kriminal itu disebabkan faktor karakter yang

\footnotetext{
43 Roby Yansyah dan Rahayu, "Globalisasi Lesbian, Gay, Biseksual, Dan Transgender (LGBT) ...,”, hal. 135. 44 Ibid.

45 Pusat Penelitian Kesehatan Universitas Indonesia. Laporan Kajian Pandangan Tokoh Agama dan Tokoh Masyarakat Terhadap Lesbian, Gay, Biseksual, dan Transgender (LGBT) di Jakarta, Bogor, Depok, dan Tangerang. Jakarta: Kementerian Pemberdayaan Perempuan dan Anak, 2015, hal. 26-27.
} 
posesif kepada pasangan sesama jenisnya. ${ }^{46}$ Susan C. Turell dalam penelitiannya yang dimuat di dalam "Journal of Family Violence" mendapatkan hasil bahwa laki-laki gay mendapatkan kekerasan dari pasangan sesama jenisnya, yaitu 44\% berupa kekerasan fisik dan kekerasan seksual sebesar 13\%, sedangkan untuk perempuan lesbian mendapatkan 55\% kekerasan fisik dan 14\% kekerasan seksual dari pasangan lesbiannya. ${ }^{47}$ Akibat dari faktor kejiwaan tersebut maka kelompok homoseksual memiliki kecenderungan melakukan kejahatan, karena kekurangmampuan jiwa mereka mengontrol dirinya atas kecemburuan, sakit hati terhadap seseorang dan lain sebagainya. Entitas keberadaan LGBT dengan berbagai macam persoalan membangun persepsi masyarakat bahwa LGBT (termasuk homoseksual) sering dianggap berkonotasi dengan kasus kekerasan seksual pada sesama jenis, baik terhadap orang dewasa maupun terhadap anak-anak. ${ }^{48}$

\section{B. Homoseksualitas Ditinjau dari Perspektif Norma Keindonesiaan}

Sebagai bangsa yang beradab, Indonesia menjunjung tinggi nilai moralitas. Pancasila sebagai ideologi bangsa merupakan cerminan dari diakuinya moralitas yang menjunjung nilai-nilai kebaikan yang otoritatif. Pancasila merupakan sumber dari segala sumber hukum, hakikatnya adalah tempat menemukan dan menggali hukum. Roeslan Saleh berpendapat fungsi Pancasila dalam bidang hukum adalah sebagai: $^{49}$ pertama, Ideologi hukum; kedua, kumpulan nilai-nilai yang harus menjiwai setiap hukum; ketiga, asas-asas yang harus diikuti dalam mengadakan pilihan hukum; dan keempat, suatu pernyataan dari nilai kejiwaan

46 Ani Khairani dan Didin Saefudin, "Homoseksual Nerdasarkan Pandangan Psikologi Islam”..., hal. 116.

47 Susan C. Turel, "A Descriptive Analysis of Same-Sex Relationship Violence for a Diverse Sample", Journal of Family Violence, Vol. 15, No. 3, 2000, hal. 287.

48 Elga Andina, "Faktor Psikososial dalam Interaksi Masyarakat dengan Gerakan LGBT di Indonesia", Aspirasi, Vol. 7, No. 2, Desember 2016, hal. 173-185.

49 Fais Yonas Bo'a, "Pancasila sebagai Sumber Hukum dalam Sistem Hukum Nasional”, Jurnal Konstitusi, Vol.15, No. 1, 2018, hal. 27-49. dan keinginan bangsa Indonesia dalam hukum. Pancasila, sebagai dasar falsafah dan ideologi bangsa Indonesia, merupakan suatu identitas masyarakat atau bangsa, atau yang dikenal dengan sebutan kepribadian bangsa. Sebagai ideologi, Pancasila mencakup seluruh aspek kehidupan yang mencakup politik, pendidikan, agama, budaya, sosial dan ekonomi. ${ }^{50}$ Seluruh aspek tersebut diwajibkan selaras dengan dan tidak bertentangan dengan Pancasila.

Nilai-nilaiyang terkandungdalamPancasila, salah satunya adalah sila Ketuhanan Yang Maha Esa menunjukkan bahwa hukum harus sejalan dengan ketentuan-ketentuan Tuhan yang tercermin dari ajaran-ajaran agama. Pancasila mengandung nilai moralitas objektif yang berasal dari ajaran-ajaran agama yang secara otoritatif diakui sebagai ukuran menentukan baik dan buruknya sesuatu. ${ }^{51}$ Selain moralitas objektif, terdapat pula yang disebut dengan moralitas subjektif yang berangkat dari perasaan hati nurani dalam menilai baik dan buruk suatu perbuatan.52 Menurut penulis, moral sendiri merupakan norma yang otoritatif diakui oleh agama ataupun oleh masyarakat. Hakim Devlin, seorang hakim di Inggris, menyatakan bahwa moralitas merupakan eksistensi dari masyarakat yang beradab, sehingga perbuatan yang bertentangan dengan moral dipandang sebagai penghianatan terhadap eksistensi masyarakat..$^{53}$

Masyarakat Indonesia memandang persoalan homoseksualitas sebagai hal yang

50 Syahrul Kirom, "Filsafat Ilmu dan Arah Pengembangan Pancasila: Relevansinya dalam Mengatasi Persoalan Kebangsaan”, Jurnal Filsafat, Vol. 21, No. 2, 2011, hal. 99. 117.

$51 \quad$ Ibid.

52 Hati nurani sebagai patokan moralitas teridentifikasi melalui sikap hati nurani terhadap tindakan yang dilakukan. Reaksi hati nurani terhadap perbuatan baik terlihat dari perasaan tenteram, sedangkan perbuatan buruk akan menimbulkan kegelisahan. Lihat: Salman Luthan. "Dialektika Hukum dan Moral dalam Perspektif Filsafat Hukum”. Jurnal Hukum Ius Quia Iustum, No. 4, Vol. 19, 2012, hal. 506-523.

53 Lidya Suryani Widayati, "Kebijakan Kriminalisasi Kesusilaan dalam Rancangan Undang-undang" ..., hal. 181-198. 
tabu dan bertentangan dengan fitrah manusia. ${ }^{54}$ Agama Islam menyinggung persoalan homoseksualitas di dalam Surat Al-Ankabut ayat 28-35 mengenai kisah Nabi Luth AS yang menentang budaya homoseksualitas yang dianut oleh kaumnya (kaum Sodom). Majelis Ulama Indonesia telah mengeluarkan fatwa terkait perbuatan homoseksual yang pada intinya mengharamkan perbuatan tersebut, tetapi yang perlu digarisbawahi dari fatwa tersebut adalah bahwa homoseksual merupakan kelainan yang itu harus disembuhkan. ${ }^{55} \mathrm{Hal}$ tersebut kiranya sesuai dengan pandangan ilmiah yang menempatkan faktor psikis atau kejiwaan serta faktor lingkungan sebagai penyebab terjadinya penyimpangan seks, tidak terkecuali homoseksual..$^{56}$

Alkitab (bible) dalam Petrus ayat 6-8 mengatakan yang demikian pula menyatakan perbuatan sodomi adalah perbuatan yang tidak senonoh dan bejat. Entitas nilai-nilai agama sebagai sumber moralitas menujukkan penolakannya terhadap perbuatan homoseksual menujukkan homoseksual adalah perbuatan yang amoral atau perbuatan yang tercela. ${ }^{57}$ Lebih lanjut Paus Benekdiktus XVI sebagai pimpinan umat katolik Roma menyatakan bahwa Gereja Katolik melarang pernikahan sesama jenis dan menentang aborsi. ${ }^{58}$ Agama Hindu pun melarang adanya perkawinan sejenis, walaupun dalam ajarannya tidak secara tersurat melarang homoseksual tetapi hal tersebut tidak memberikan kebahagian dan keturunan sebagaimana tujuan perkawinan di dalam ajaran Hindu. ${ }^{59}$ Begitu juga agama Konghucu, yang menekankan tujuan perkawinan yang harmonis untuk mendapatkan keturunan

54 Pusat Penelitian Kesehatan Universitas Indonesia, Laporan Kajian Pandangan Tokoh Agama Dan Tokoh Masyarakat Terhadap Lesbian, Gay, Biseksual, dan Transgender (LGBT) ..., hal. 21.

55 Ibid., hal. 2.

56 Kelly Brook. Education of Sexuality for Teenager..., hal. 89.

57 Sana Loue, "Case Studies in Society, Religion, And Bioethics" ..., hal. 14-15. Lihat juga: Syafi'in Mansur, "Homoseksual dalam Perspektif Agama-Agama di Indonesia”, Jurnal Aqlania, Vol. 08, No. 01, 2017, hal. 27-49.

58 Ibid., hal. 44.

59 Ibid., hal. 47. sehingga hal tersebut tidak dapat dicapai jika pernikahan dilakukan sesama jenis. ${ }^{60}$ Tidak berbeda jauh dengan agama Hindu dan agama Konghucu, agama Budha pun melarang adanya penyimpangan seksual sebagaimana yang tertuang di Pancasila Budhis sila ke-3. ${ }^{61}$

Pendapat berbagai tokoh agama ataupun masyarakat yang menolak homoseksualitas sedikit banyak akan bersinggungan dengan isu-isu Hak Asasi Manusia (HAM), khususnya mengenai universalisme HAM. Universalitas HAM didasarkan pada pendapat John Locke yang mengemukakan bahwa HAM sebagai hak manusia yang bersifat prinsip sejak manusia dilahirkan, bukan atas pemberian negara, dan hak tersebut tidak dapat dicabut maupun dipindahtangankan. ${ }^{62}$ Mahfud MD kemudian memodifikasi pendapat Jhon Locke dengan mendefinisikan HAM sebagai hak yang bersifat kodrati yang dimiliki setiap manusia sebagai makhluk ciptaan Tuhan, dan hak tersebut dibawa manusia sejak lahir ke muka bumi bukan merupakan pemberian dari manusia atau negara. ${ }^{63}$ Lebih lanjut, Miriam Budiardjo mengkonsepsikan HAM sebagai hak-hak yang dimiliki oleh manusia yang telah diperoleh dan dibawanya bersamaan dengan kelahiran dan kehadirannya dalam hidup masyarakat. Hak ini ada pada manusia tanpa membedakan bangsa, ras, agama, golongan, jenis kelamin, karena itu bersifat asasi dan universal. Dasar dari semua hak asasi adalah bahwa semua orang harus memperoleh kesempatan berkembang sesuai dengan bakat dan cita-citanya. ${ }^{64}$ Sifat-sifat universal yang dimiliki HAM tersebut lah yang kemudian memunculkan perdebatan dengan persoalan relativisme budaya. Semisal pendapat Johann Gottfried von Herder,
Ibid., hal. 52 .
Ibid., hal. 49.
Belardo Mega Jaya dan Muhammad Rusli Arafat, "Universalism vs. Cultural Relativism dan Implementasinya dalam Hak Kebebasan Beragama di Indonesia", Pena Justisia: Media Komunikasi dan Kajian Hukum, Vol. 17, No. 2, 2017, hal. 57-65.
63 Erlina B, "Pengaruh Globalisasi Terhadap Perkembangan Hak Asasi Manusia Bidang Ekonomi, Sosial, Budaya (HESB) di Indonesia", Pranata Hukum, Vol. 6, No. 2, Juli 2011, hal. 103-116.
64 Sri Rahayu Wilujeng, "Hak Asasi Manusia: Tinjauan dari Aspek Historis dan Yuridis", Humanika, Vol. 18, No.2, Juli 2013, hal. 1-10. 
yang menegaskan bahwa setiap negara memiliki keunikan sendiri, universalisme merupakan suatu kebohongan. ${ }^{65}$ Pandangan von Herder tersebut sedikit banyak dibenarkan oleh pakar hukum progresif Indonesia, yaitu Satjipto Rahardjo. Beliau berpendapat bahwa penerapan HAM sebenarnya berbeda-beda di setiap negara karena disesuaikan dengan sejarah, keadaan sosial, ekonomi, dan budaya suatu negara. HAM memiliki watak dan struktur sosialnya sendiri, menyesuaikan dengan keberadaan lingkungan sosial atau habitat masyarakat tempat HAM tersebut berkembang. ${ }^{66}$

Perdebatanuniversalitas HAMdan relativitas budaya tersebut, sedikit banyak berimplikasi pula terhadap perbedaan kebijakan terkait eksistensi homoseksualitas di suatu negara, khususnya mengenai isu legalisasi pernikahan sejenis. Ada beberapa negara yang melegalkannya, seperti Belanda (2000), Belgia (2003), Spanyol (2005), Afrika Selatan (2006), dan yang paling baru adalah Malta, Australia, dan Jerman (ketiganya di tahun 2017). ${ }^{67}$ Tetapi tidak sedikit pula negara yang menolak homoseksual. Di wilayah ASEAN terdapat negara Brunai Darussalam dengan pemberlakuan hukum Syariah/Islam yang ketat. Kemudian Singapura yang melarang perbuatan seksual sesama jenis di dalam Pasal 377A KUHP Singapura. ${ }^{68}$ Ada pula Rusia sejak tahun 2013, bahkan hingga melarang tindakan publik kelompok pembela hak LGBT, serta segala bentuk hiburan yang mengandung cerita atau karakter homoseksual. ${ }^{69}$

Ibid.

66 Yuli Asmara Triputra, "Implementasi Nilai-Nilai Hak Asasi Manusia Global ke dalam Sistem Hukum Indonesia yang Berlandaskan Pancasila”, Jurnal Hukum Ius Quia Iustum, No. 2, Vol. 24, April 2017, hal. 272-300.

67 Michael Owusu Tabiri, "Same-Sex Marriage: Secular and Religious Views". Journal of Educational System, Vol. 3, No. 11, 2019, hal. 4-10.

68 Indra Tua Hasangapon Harahap, Iqbal Kamalludin, dan Nila Arzaqi, "Kebijakan Hukum Pidana dalam Upaya Menanggulangi LGBT (Lesbian, Biseksual, dan Transgender) Berbasis Pancasila", Masalah-Masalah Hukum, Vol. 47, No.4, Oktober 2018, hal. 400-412.

69 Aturan tersebut didukung oleh $88 \%$ warga Rusia. Lihat: BBC News, 4 April 2019 "Selain Brunei, Negara Mana Saja yang Berlakukan Hukuman Mati bagi LGBT?” https://www. bbc.com/indonesia/majalah-47796268, diakses tanggal 22 Desember 2019.
Terkait persoalan homoseksualitas maupun isu legalisasi pernikahan di Indonesia, penulis lebih mengacu pada pandangan Satjipto Rahardjo yang melihat HAM dengan watak dan struktur sosialnya masing-masing. ${ }^{70}$ Sehingga HAM Indonesia juga memiliki kultur, watak dan ideologi yang berbeda dengan negara lainnya, karena HAM Indonesia berbasis pada nilai-nilai Pancasila. Selain penekanan nilai-nilai Ketuhanan yang termaktub di sila pertama, Pancasila juga menekankan persoalan kemanusiaan yang terdapat di sila ke-2. Sila ke-2 tersebut menyandingkan perihal kemanusiaan, keadilan, dan keberadaban, yang itu merupakan nilai kompromi terbaik untuk mewujudkan cita-cita keadilan sosial bagi seluruh rakyat Indonesia (sebagaimana yang diamanatkan di sila ke-5), ditengah-tengah perdebatan persoalan homoseksualitas maupun desakan mengenai persoalan legalisasi pernikahan sejenis. Keseimbangan monodualistik sebagai filosofi keadilan yang terkandung di dalam Pancasila, menekankan pada keseimbangan antara kepentingan individu/pribadi dan kepentingan umum (masyarakat dan negara). Sehingga keberadaan homoseksualitas di tengah-tengah kehidupan masyarakat Indonesia masih dapat diterima sebagai hak privat/pribadi masing-masing individu, sepanjang hal tersebut tidak mengganggu kepentingan/hak masyarakat lainnya (dalam hal ini yang dimaksud adalah hak atas rasa kesusilaan dan kesopanan). Konflik yang terjadi terkait persoalan homoseksualitas kebanyakan terjadi ketika komunitas ini melakukan perbuatan-perbuatan yang meresahkan masyarakat, semisal melakukan kejahatan seksual, pesta seks atau upayaupaya menuntut adanya legalisasi pernikahan sejenis. Begitu juga masyarakat, perlu untuk menghilangkan stigmatisasi dan homophobia ${ }^{71}$

\footnotetext{
Yuli Asmara Triputra, "Implementasi Nilai-Nilai Hak Asasi Manusia Global ...”, hal. 293.

71 Homophobia adalah ketakutan irasional terhadap homoseksualitas. Masalah ini juga didefinisikan sebagai ketakutan atau kebencian terhadap lesbian dan lelaki gay. Lihat: Husmiati, "Working with Homosexual Clients: Application of Solution-Focused Therapy", Jumal Psikologi Undip, Vol. 11, No.1, April 2012. hal. 11-18.
} 
yang berdampak terhadap terganggunya para LGBT (tidak terkecuali homoseksual) dalam mendapatkan hak asasinya, seperti hak medapatkan penghidupan yang layak, hak untuk menjalankan ibadah, atau hak untuk memperoleh kesehatan maupun pendidikan yang layak. Upaya-upaya para homoseksual untuk coming out perlu untuk memperhatikan konsekuensi dari pilihannya tersebut, sehingga perlu untuk mendapatkan pendampaingan dari psikolog maupun psikiater. Termasuk juga untuk berusaha mengubah penyimpangan yang dideritanya tersebut.

\section{Sekilas tentang Delik Kesusilaan dalam Hukum Pidana Positif Indonesia dan Rancangan KUHP Nasional 2019}

KUHP Indonesia saat ini merupakan warisan/peninggalan Belanda yang dulu disebut dengan Weet Boek van Strafrecht (WvS), yang diberlakukan sebagai hukum pidana Indonesia melalui Undang-Undang Nomor 1 Tahun 1946 tentang Peraturan Hukum Pidana. Sebagai bagian dari warisan Belanda, maka KUHP sedikit banyak masih bernuansa kolonial dan juga bercita rasa hukum barat. ${ }^{72}$ Sehingga terdapat beberapa hal yang tidak harmonis antara KUHP sebagai hukum pidana positif Indonesia dengan celaan moral di dalam hukum adat maupun hukum agama yang dianut oleh masyarakat. Tidak terkecuali delik-delik yang berkaitan dengan persoalan kesusilaan, yang beberapa diantaranya dipandang sudah tidak relevan dengan perkembangan perilaku manusia, atau beberapa kejahatan yang belum terakomodir di dalam KUHP saat ini.

Terdapat beberapa delik kesusilaan di dalam KUHP, baik itu berbentuk Kejahatan (dalam Buku II, Bab XIV Pasal 281 s/d Pasal 303), maupun berbentuk Pelanggaran (dalam Buku III, Bab VI Pasal 532 s/d 547). Satochid Kartanegara, menyebutkan bahwa ada 3 (tiga) kepentingan hukum yang hendak dilindungi

72 Indonesia pernah menjadi koloni Belanda kurang lebih selama 350 tahun. Hal tersebut sedikit benyak berimpact terhadap kehidupan sosial dan budaya masyarakat Indonesia, tidak terkecuali dalam hal sistem maupun peraturan hukum yang ada. oleh hukum pidana, yaitu kepentingan individu (individuale belangen), kepentingan masyarakat (sociale belangen), dan kepentingan negara (staatsbelangen). ${ }^{73}$ Individuale belangen terbagi lagi menjadi 3 (tiga) kepentingan, yaitu mengenai nyawa/hak hidup, mengenai benda/hak kebendaan, dan mengenai perasaan atau kehormatan. ${ }^{74}$ Mengenai kesusilaan, hal tersebut digolongkan dalam bagian kepentingan perasaan, baik itu yang bersifat individu maupun masyarakat. Sehingga pelanggaran terhadap kepentingan kesusilaan yang dimiliki seseorang akan serta merta melanggar rasa kesusilaan yang dimiliki oleh orang yang lainnya atau masyarakat, sebagaimana yang dijelaskan oleh Adami Chazawi mengenai delik pornografi. ${ }^{75}$

Sejatinya di dalam KUHP tidak ada delik yang menempatkan homoseksualitas sebagai tindak pidana. Hanya saja ada beberapa delik atau tindak pidana yang sangat erat dilatarbelakangi oleh perilaku homoseksualitas. Pertama, Pasal 292 KUHP, yang berbunyi: "Orang dewasa yang melakukan perbuatan cabul dengan orang yang belum dewasa dari jenis kelamin yang sama, sedang diketahuinya atau patut harus disangkanya hal belum dewasa itu, dihukum penjara selama-lamanya lima tahun". ${ }^{76}$ Pasal tersebut merupakan bentuk perlindungan orang-orang yang belum dewasa dari kejahatan kesusilaan yang dikenal saat ini dengan istilah pedofilia. Kedua, Pasal 289 KUHP yang bunyinya sebagai berikut:

73 Adami Chazawi, Tindak Pidana Pornografi; Penyerangan Terhadap Kepentingan Hukum Mengenai Tegaknya Tatanan Kehidupan Akhlak dan Moral Kesusilaan yang Menjunjung Tinggi Nilai-nilai Ketuhanan yang Maha Esa dan Kemanusiaan yang Adil dan Beradab, Surabaya: CV Putra Media Nusantara, 2009, hal. 4.

Ibid., hal. 5.

Ibid.

Pada rumusan tersebut terdapat unsur "perbuatan cabul", yang akan berkaitan dengan dua unsur lainnya, yaitu unsur "dengan orang yang belum dewasa" dan unsur "dari jenis kelamin yang sama" (kedua unsur terakhir merupakan syarat khusus delik). Menurut penulis, titik tercelanya (celaan) perbuatan tersebut terletak pada adanya korban berupa anak/belum dewasa, atau dengan kata lain adanya pasal tersebut adalah untuk melindungi kepentingan pribadi si anak, dan kepentingan kesusilaan masyarakat. 
"Barang siapa dengan kekerasan atau ancaman maka aturan-aturan tersebut tampak dari tabel kekerasan memaksa seorang untuk melakukan 1 .

Tabel. 1 Perbandingan Pengaturan tentang Perilaku Homoseksual

\begin{tabular}{|c|c|c|}
\hline Peraturan & Pasal & Keterangan \\
\hline \multirow{2}{*}{$\begin{array}{l}\text { UU } 44 \text { Tahun } \\
2008 \text { tentang } \\
\text { Pornografi }\end{array}$} & 4 (Penjelasan) & $\begin{array}{l}\text { "Yang dimaksud dengan persenggamaan yang menyimpang antara lain } \\
\text { persenggamaan atau aktivitas seksual lainnya dengan mayat, binatang, oral seks, } \\
\text { anal seks, lesbian, dan homoseksual". }{ }^{8}\end{array}$ \\
\hline & $\begin{array}{l}1 \text { angka } 1 \text { Jo. } \\
\text { Pasal-pasal } \\
\text { dalam UU } \\
\text { tersebut yang } \\
\text { terkait }\end{array}$ & $\begin{array}{l}\text { "Pornografi adalah gambar, sketsa, ilustrasi, foto, tulisan, suara, bunyi, gambar } \\
\text { bergerak, animasi, kartun, percakapan, gerak tubuh, atau bentuk pesan lainnya } \\
\text { melalui berbagai bentuk media komunikasi dan/atau pertunjukan di muka umum, } \\
\text { yang memuat kecabulan atau eksploitasi seksual yang melanggar norma kesusilaan } \\
\text { dalam masyarakat". }{ }^{9}\end{array}$ \\
\hline $\begin{array}{l}\text { UU } 11 \text { Tahun } \\
2008 \text { tentang } \\
\text { ITE }\end{array}$ & 27 jo. 52 & $\begin{array}{l}\text { Secara tersurat, tidak ada ketentuan terkait homoseksual maupun mengenai } \\
\text { perbuatan cabul sesama jenis. Tetapi secara tersirat terdapat di Pasal } 27 \text { jo. } \\
\text { Pasal 52, yang menyebutkan frasa "muatan yang melanggar kesusilaan". }{ }^{80}\end{array}$ \\
\hline
\end{tabular}

Sumber: diolah sendiri dari berbagai sumber

atau membiarkan dilakukan perbuatan cabul, diancam karena melakukan perbuatan yang menyerang kehormatan kesusilaan, dengan pidana penjara paling lama sembilan tahun". Rumusan Pasal 289 tersebut memandang perbuatan cabul secara luas. Maksudnya, perbuatan cabul di sini tidak terbatas pada korban yang sesama jenis, tetapi mencakup juga terhadap korban yang berbeda/berlainan jenis. ${ }^{77}$

Selain di dalam KUHP, delik-delik kesusilaan juga terdapat di luar KUHP. Diantaranya terdapat di dalam Undang-undang Nomor 44 Tahun 2008 tentang Pornografi, dan Undang-undang Nomor 11 Tahun 2008 tentang Informasi dan Transaksi Elektronik. Jika dikaitkan dengan objek dalam tulisan ini, yaitu mengenai persoalan perilaku homoseksual,

77 KUHP membedakan antara "perbuatan cabul" dengan perbuatan "persetubuhan/bersetubuh". "Persetubuhan" diartikan sebagai perbuatan memasukkan alat kelamin laki-laki ke dalam alat kelamin perempuan. Arrest Hooge Raad 5 Februari 1912 mendefinisikan persetubuhan sebagai peraduan dua alat kelamin hingga mengeluarkan cairan sperma. Dengan demikian "perbuatan cabul" sendiri merupakan perbuatan yang tidak berbentuk persetubuhan, tetapi menciderai nilai/rasa kesusilaan. Tetapi Pasal 289 tersebut titik pencelaannya terletak pada persoalan "adanya kekerasan atau ancaman kekerasan”. Kekerasan atau ancaman kekerasan tersebut dilakukan karena korban sebenarnya tidak menghendaki atas perbuatan cabul terhadap dirinya. Lihat: R. Soesilo. Kitab Undang-Undang Hukum Pidana (KUHP) Serta Komentar-Komentarnya Lengkap Pasal Demi Pasal. Bogor: Politea, 1995, hal. 209.
Memperhatikan tabel tersebut maka diketahui bahwa tidak ada aturan yang secara spesifik/khusus melarang perilaku homoseksual. Larangan itu baru muncul ketika:

a. Terdapat perbuatan lain yang mengakibatkan perbuatan homoseksual tersebut masuk ke ranah publik; atau

b. Jika perbuatan homoseksual tersebut melibatkan anak; atau

c. Adanya unsur paksaan yang diderita oleh korbannya.

Sedangkanuntukperbuatan persenggamaan sesama jenis terhadap orang dewasa atas dasar

78 Ketentuan tersebut paling tidak menggambarkan bahwa homoseksual dipandang sebagai bentuk orientasi seksual yang menyimpang.

79 Ketentuan tersebut jika dikaitkan dengan persoalan homoseksual sebagai bentuk "persenggamaan yang menyimpang" sebagaimana ketentuan Pasal 4. Dengan demikian, perilaku homoseksual tidak dapat dijerat UU Pornografi jika tidak diikuti unsur "di muka umum". Unsur tersebut merupakan batas masuknya persoalan privat/pribadi ke ranah publik.

80 Perbuatan bermuatan unsur pencabulan sesama jenis dapat dinilai dan dipandang masuk sebagai perbuatan yang melanggar kesusilaan. Tetapi tidak berbeda jauh dengan UU Pornografi, bahwa ketentuan dalam UU ITE tersebut juga berkaitan dengan perbuatan lain (tidak semata melanggar kesusilaan) tetapi ada perbuatan lain yang membuat perbuatan asusila tersebut memasuki wilayah publik, yaitu perbuatan: "mendistribusikan dan/atau mentransmisikan dan/atau membuat dapat diaksesnya Informasi Elektronik dan/atau Dokumen Elektronik". 
suka sama suka, selama tidak diikuti ketiga perbuatan lain di atas, maka hal tersebut tidak dapat dikenakan sanksi pidana.

Jika mengacu pada RKUHP Nasional 2019 sebagai gambaran ius constituendum hukum pidana Indonesia maka di dalamnya masih mengatur mengenai delik-delik kesusilaan yang termuat dalam BAB XVI tentang Kesusilaan dan BAB XXIV tentang Tindak Pidana Terhadap Tubuh. Diantaranya adalah: inses (Pasal 442 ayat (1); persetubuhan di luar perkawinan (Pasal 436); melakukan perbuatan cabul (Pasal 438); dan perluasan makna perkosaan (Pasal 499). Rancangan tersebut menghilangkan beberapa ketentuan terkait unsur-unsur tindak pidana yang menggambarkan adanya latar belakang homoseksual, terutama mengenai pencabulan terhadap anak yang sesama jenis. ${ }^{81}$ Rancangan tahun 2019 tersebut semakin menggambarkan adanya batasan yang sangat jelas, bahwa perilaku homoseksual merupakan suatu yang bersifat pribadi/privat, sehingga selama itu tidak diwujudkan sebagai suatu perbuatan yang memasuki wilayah publik maka hal tersebut bukan merupakan tindak pidana.

Terlepas dari delik-delik bersifat kesusilaan yang telah dijabarkan di atas, homoseksualitas dapat menjadi pemicu terjadinya kejahatan lain di luar delik kesusilaan tersebut. Hal tersebut tergambar dari beberapa kasus yang pernah menjadi sorotan publik, seperti kasus Ryan Jombang yang membunuh dan memutilasi korbannya atas dasar homoseksualitas, atau kasus pembunuhan sadis dan mutilasi yang dilakukan YN terhadap NA karena latar belakang homoseksualitas, ${ }^{82}$ atau berbagai kasus sodomi terhadap anak-

81 Hal tersebut berbeda dengan rancangan tahun 2015, yang masih menggunakan unsur-unsur berlatar belakang homoseksualitas.

82 YN dan NA yang merupakan pasangan sesama jenis, terlibat pertikaian hingga YN melakukan pembunuhan serta memutilasi alat kelamin NA sesaat setelah pembunuhan terjadi. Teguh Firmansyah, 31 Mei 2016, Ini Kronologi Pembunuhan Pasangan Sejenis di Bogor. https:// www.republika.co.id/berita/nasional/daerah/16/05/31/ o81ghn377-ini-kronologi-pembunuhan-pasangan-sejenisdi-bogor, diakses tanggal 27 Maret 2020. anak. ${ }^{83}$ Ditetapkannya homoseksualitas bukan sebagai gangguan mental kejiwaan/ kepribadian menurut DSM-2 berdampak pada pertanggungjawaban pidana dalam perkara tersebut, sehingga pelaku kejahatan yang dilatarbelakangi perilaku homoseksual dapat dimintai pertanggungjawaban secara pidana sebagaimana orang normal pada umumnya.

\section{Gagasan Double Track System terhadap Pelaku Tindak Pidana yang dilatarbelakangi oleh Perilaku Homoseksualitas}

\section{A. Pidana dan Pemidanaan dalam Dimensi Pembaruan Hukum Pidana Indonesia}

"Pidana" dan "pemidanaan" memiliki hubungan yang sangat erat, karena "pemidanaan" dapat diartikan sebagai "pemberian atau penjatuhan sanksi pidana" ${ }^{84}$ Roeslan Saleh menyatakan bahwa pidana adalah reaksi atas delik dalam wujud nestapa yang sengaja ditimpakan negara kepada pembuat delik. ${ }^{85}$ Sedikit berbeda adalah pendapat Hoefnagels ${ }^{86}$, yang mendefinisikan

83 Kasus sodomi yang pernah terjadi dilakukan oleh seorang guru ngaji di Kota Malang yang melakukan sodomi terhadap muridnya, hal itu dilakukan puluhan kali kepada beberapa muridnya. Lihat: Benni Indo, 9 Mei 2018, Tiga Bocah di Malang Jadi Korban Sodomi, saat Terungkap, Pekerjaan Pria Pelakunya Mengejutkan, https://surabaya. tribunnews.com/2018/05/09/tiga-bocah-di-malangjadi-korban-sodomi-saat-terungkap-pekerjaan-priapelakunya-mengejutkan, diakses tanggal 15 April 2020.

84 Lihat: Muladi dan Barda Nawawi Arief, Teori-teori dan Kebijakan Pidana, Bandung: Alumni, 2010, hal. 78. Sedangkan Andi Hamzah mengartikan pidana (straf) sebagai penjatuhan hukuman terhadap orang yang terbukti bersalah melakukan delik berdasarkan putusan yang berkekuatan hukum tetap, sedangkan pemidanaan diartikan sebagai hal yang berkenaan dengan pidana, misalnya mengenai tujuan atau maksud dijatuhkannya pidana. Lihat juga: M. Sholehuddin, Sistem Sanksi Dalam Hukum Pidana (Ide Dasar Double Track System dan Implementasinya), Jakarta: PT. Raja Grafindo Persada, 2003, hal. 55.

85 Dwidja Priyatno, Sistem Pelaksanaan Pidana..., hal. 28.

86 Hoefnagels tidak setuju dengan pendapat bahwa pidana merupakan suatu pencelaan (cencure) atau suatu penjeraan (discouragement) atau suatu penderitaan (suffering). Pemberian sanksi merupakan suatu proses pembangkitan semangat (encouragement) dan pencelaan (cencure) untuk tujuan agar seseorang berorientasi atau menyesuaikan diri dengan suatu norma atau undangundang yang berlaku. Lihat: Muladi dan Barda Nawawi Arief, Teori-teori dan Kebijakan Pidana..., hal. 9-10. 
pidana sebagai semua reaksi pada pelanggaran hukum yang telah ditentukan oleh undangundang, sejak penahanan sampai dengan vonis dijatuhkan. ${ }^{87}$ Dipandang dari aspek filsafat, menurut Sue Titus Reid tujuan pemidanaan bersifat retributif di mana penjatuhan pidana (pemidanaan) adalah hal yang patut, dan pidana yang tepat akan mencegah para pelaku tindak pidana tidak mengulangi lagi perbuatannya serta mencegah orang lain melakukan tindakan kriminal. ${ }^{88}$ Lebih lanjut, Gerry A. Ferguson menuturkan, "jangan menggunakan pidana secara berlebihan karena akan menimbulkan kerugian yang lebih besar", itu berarti bahwa penjatuhan pidana harus sebanding dengan perbuatan dan kerugian yang ditimbulkan. ${ }^{89}$ Kerugian yang lebih besar tersebut persis seperti ketakutan dari Harbert L. Packer bahwa pidana apabila digunakan secara tidak cermat (berlebihan) akan menimbulkan ancaman kerusakan. ${ }^{90}$ Dampak negatif dari ketidaktepatan dalam memidana seorang pelaku kejahatan di antaranya adalah mengenai prisonisasi dan stigmatisasi.

Seorang pelanggar hukum akan memasuki dunia yang berbeda dan dirasa asing, ketika ia masuk dalam penjara. Dia akan mengenal suatu sistem sosial yang tidak pernah dirasakan sebelumnya, yaitu masyarakat narapidana (the inmate community). Kondisi yang sedemikian rupa oleh Donald Clemmer disebut sebagai prisonisasi (prisonization). ${ }^{91}$ Bernes dan Teeters

87 Dwidja Priyatno, Sistem Pelaksanaan Pidana ..., hal. 8. Mendasarkan pada pendapat Hoefnagels tersebut maka dapat menjadi renungan bahwa sejatinya pidana dan pemidanaan sudah mulai berlaku sejak seseorang pelaku kejahatan berurusan atau diproses melalui mekanisme hukum acara, atau dengan kata lain nestapa atau penderitaan sejatinya sudah dirasakan oleh seorang jauh sebelum ia diputus bersalah oleh pengadilan. Maka tidak lah salah jika terdapat adagium hukum pidana sebagai ultimum remidium (obat terakhir) karena melihat begitu beratnya akibat dari hukum pidana tersebut sehingga ia harus menjadi pilihan paling akhir dalam penyelesaian suatu persoalan kejahatan.

$88 \quad$ Ibid., hal 17.

89 M. Sholehuddin, Sistem Sanksi dalam ..., hal. 63.

90 Lilik Mulyadi. "Eksistensi Hukum Pidana Adat di Indonesia...", hal. 233.

91 Muladi dan Barda Nawawi Arief, Teori-teori dan Kebijakan Pidana ..., hal. 78. lebih lanjut mengemukakan mengenai dampak negatif lanjutan dari prisonisasi yang disebut place of contamination, yaitu penjara menjadi tempat pencemaran karena penghuni baru dalam dunia kejahatan lebih dirusak mentalnya melalui pergaulannya dengan penjahat-penjahat kronis. ${ }^{92}$ Selain prisonisasi dampak negatif pemenjaraan lainnya menurut Hoefnagels adalah stigmatisasi. $^{93}$ Stigmatisasi menurut Yesmil Anwar ${ }^{94}$ merupakan kondisi di mana seseorang mantan narapidana mendapatkan cap atau label penjahat ketika dia kembali ke masyarakat. Cap ataulabel tersebut berdampak pada terhambatnya seorang mantan narapidana untuk kembali, membaur dan diterima masyarakat sebagai orang yang lebih baik, sehingga hal tersebut berdampak terhadap usaha dia dalam menjalani kehidupan dan memenuhi kebutuhannya sebagai manusia.

Pendapat para ahli tersebut tidak lah salah dan masih relevan jika dikontemplasikan dengan fakta dan realita di Indonesia. Paradigma buruk lembaga pemasyarakatan pernah diungkapkan oleh kanal berita Detik yang melakukan penelusuran ke sejumlah lembaga pemasyarakatan di Jawa Barat dan menemukan hasil yang miris. ${ }^{95}$ Lingkungan lembaga pemasyarakatan menjadi penyebab penyimpangan perilaku terhadap narapidana, diantaranya berupa penyimpangan perilaku seksual yaitu homoseksual. Hal tersebut disebabkan oleh lingkungan yang memaksa seseorang menjadi homoseksual semisal karena tidak ada pelampiasan Hasrat seksual dan ditambah dengan lemahnya pengawasan karena petugas lapas yang membiarkan praktik tersebut demi keuntungan materi. ${ }^{96}$ Persoalan tersebut didukung pula oleh faktor over capacity lembaga pemasyarakatan.
Ibid., hal. 79.
Ibid., hal. 81.
4 Yesmil Anwar dan Adang, Pembaruan Hukum Pidana .... hal. 141.
95 Irnanda, 25 Juli 2019 "Terpaksa Menjadi Gay di Balik Jeruji Besi” https://news.detik.com/video/190725027/ terpaksa-menjadi-gay-di-balik-jeruji-besi, diakses tanggal 24 Desember 2019.
96 Aditya Yuli Sulistyawan, "Membangun Model Hukum yang Memerhatikan Kebutuhan Seksual Narapidana di Lembaga Pemasyarakatan: Telaah Paradigma Konstruktivisme”, Jurnal Ilmu Hukum, Vol. 4, No. 1, 2014, hal. 213-228. 
Tentunya hal tersebut menjadi warning mengenai sistem pemidanaan maupun penegakan hukum pidana di Indonesia yang hanya menekankan pada pemenjaraan sebagai sanksi utama, yang itu justru menimbulkan kerusakan yang lebih besar.

Pada prinsipnya pemidanaan merupakan variable krusial dalam sistem hukum pidana suatu negara, sehingga pemidanaan harus memiliki tujuan agar sanksi yang dijatuhkan memiliki manfaat serta tidak menimbulkan kerugian yang lebih besar. Pidana dalam literatur hukum pidana digunakan sebagai alat mencapai tujuan (purposive system) sehingga kebijakan pemidanaan harus berlandaskan nilai-nilai yang bisa merepresentasikan keberhasilan tujuan pemidanaan. Tujuan pemidanaan tidak dapat dipisahkan dari apa yang disebut dengan filsafat pemidanaan, karena di dalam filsafat pemidanaan tersebut bersemayam mengenai ide-ide dasar pemidanaan yang menjernihkan pemahaman tentang hakikat pemidanaan. ${ }^{97}$ Salah satu filsafat pemidanaan yang dikenal adalah pemidanaan yang bersumber dari filsafat eksistensialisme dari Albert Camus. ${ }^{98}$ Pemidanaan yang bersumber dari filsafat eksistensialisme tersebut kemudian melahirkan dua teori besar mengenai tujuan pemidanaan, yaitu: teori Absolut (retributive) ${ }^{99}$ dan teori Relatif/utility. ${ }^{100}$

Terkait pembaruan hukum pidana di Indonesia, mengenal adanya filsafat pemidanaan

$97 \quad$ Fungsi fundamental yaitu sebagai landasan dan asas normatif atau kaidah yang memberikan pedoman, kriteria, dan paradigma terhadap pidana dan pemidanaan. Sedangkan fungsi teori yaitu yang melandasi setiap teori pemidanaan. Dalam: M. Sholehuddin, Sistem Sanksi dalam ..., hal. 80.

98 Filsafat eksistensialisme dari Albert Camus berpandangan, punishment sebagai konsekuensi dari kebebasan yang disalahgunakan. Lihat: Ibid., hal. 85.

99 Pidana dalam teori absolut dipengaruhi oleh hukum pidana klasik. Pidana marupakan sarana pembalasan secara mutlak bagi pelaku kejahatan. Tujuannya untuk mengadili pelaku kejahatan atas nama negara. Lihat: Eddy O.S Hiariej, Prinsip-prinsip Hukum Pidana, Yogyakarta: Cahaya Atama Pustaka, 2014, hal. 31.

100 Pidana sebagai sistem tidak hanya bertujuan melakukan pembalasan, tetapi pidana memiliki tujuan yang lebih bermanfaat. Kemanfaatan sebagai tujuan pemidanaan dapat dicapai melalui rehabilitasi terhadap pelaku. Tujuan perbaikan bagi pelaku ini menurut von Feuerbach adalah prevensi khusus agar pelaku tidak mengulangi perbuatannya lagi di kemudian hari. Ibid. hal. 34 . yang didasarkan pada Pancasila, ${ }^{101}$ dimana pidana dan pemidanaan dicita-citakan untuk mewujudkan keseimbangan dan keselarasan antara kepentingan individu, masyarakat, dan negara, yang disebut oleh Barda Nawawi Arief sebagai keseimbangan monodualistik. ${ }^{102}$ Lebih lanjut Muladi menjelaskan bahwa penjatuhan pidana dibenarkan manakala bersifat retributive teleologis, ${ }^{103}$ sebagaimana yang tercermin dalam prinsip restorative justice yang dibangundarinilai-nilai tradisionalyang menghargai HAM Indonesia. ${ }^{104}$ Tujuan pemidanaan sebagai cerminan filsafat Pancasila sebagaimana yang telah penulis jabarkan di atas, tercermin di dalam Pasal 52 RKUHP Nasional draft 2019, ${ }^{105}$ yang

101 Pemidanaan dalam perspektif Pancasila haruslah berorientasi pada prinsip-prinsip: 1). Pengakuan manusia Indonesia adalah sebagai makhluk Tuhan YME; 2). Pengakuan tentang keluhuran harkat dan martabat manusia sebagai ciptaan Tuhan YME, sehingga pemidanaan tidak boleh menciderai dan merendahkan harkat dan martabat seorang manusia; 3). Menumbuhkan solidaritas kebangsaan dengan orang lain sebagai sesama bangsa Indonesia; 4). Menumbuhkan kedewasaan sebagai warga negara yang berkhidmat, mampu mengendalikan diri, berdisiplin dan menghormati serta menaati hukum sebagai wujud keputusan rakyat; 5). Menumbuhkan kesadaran akan kewajiban setiap individu sebagai makhluk sosial yang menjunjung keadilan bersama dengan orang lain sebagai sesama warga masyarakat. M. Sholehuddin, Sistem Sanksi Dalam ..., hal. 106-110.

102 Brian. Z. Tamanaha yang menyatakan bahwa hukum merupakan cerminan masyarakat (social order). Lihat: Brian Z. Tamanaha, "Law and Society", di dalam Patterson dan Dennis (editor/s), A Companion to Philosophy of Law and Legal Theory, 2nd ed, Oxford: Wiley-Blackwell, 2010, hal. 368.

103 Ibid. Hal 58. Retributive teleologis adalah tujuan pemidanaan yang menggabungkan retributivisme dengan utilitarianisme dalam pelaksanaan pemidanaan, atau dengan kata lain menyatukan prinsip teologis berupa kemanfaatan berkaitan dengan pelaku/pembuat untuk memperbaikinya dan prinsip retributif melalui sanksi pidana.

104 Menurut Daniel W. Van Ness, restorative justice memiliki kehendak mencapai penyelesaian konflik dan pemulihan. Lihat: Dwidja Priyatno, Sistem Pelaksanaan Pidana ..., hal. 15.

105 Tujuan pemidanaan menurut Pasal 52 ayat (1) meliputi: pertama, "mencegah dilakukannya tindak pidana dengan menegakkan norma hukum demi pelindungan dan pengayoman masyarakat"; kedua, "memasyarakatkan terpidana dengan mengadakan pembinaan dan pembimbingan agar menjadi orang yang baik dan berguna"; ketiga, "menyelesaikan konflik yang ditimbulkan akibat tindak pidana, memulihkan keseimbangan, serta mendatangkan rasa aman dan damai dalam masyarakat"; dan keempat, "menumbuhkan rasa penyesalan dan membebaskan rasa bersalah pada terpidana". Selain itu pada ayat (2) menerangkan bahwa "pemidanaan tidak dimaksudkan untuk merendahkan martabat manusia." 
ditujukan tidak hanya sebatas pada pembalasan, melainkan lebih ditujukan untuk melakukan pencegahan. Tujuan pemidanaan dalam RKUHP 2019 memadukan antara penegakan hukum pidana dengan pencegahan dalam rangka upaya pengayoman masyarakat. ${ }^{106}$

\section{B. Kaitan Double Track System dengan Tujuan Pemidanaan yang Berhaluan pada Pembaruan Hukum Pidana}

Perkembangan hukum pidana ditengah nuansa pembaruan hukum, mendorong pergeseran orientasi pemidanaan yang lebih menekankan kepada perbaikan pelaku, bukan bertujuan pembalasanyangbercorak kantianisme. Tetapi, sebagaimana pendapat Gaber dan McAnany, bahwa pidana amatlah penting dan tidak mungkin disingkirkan di tengah hegemoni tindakan (pembinaan/perbaikan pelaku), sebab rehabilitasi yang berlebihan tanpa sanksi pidana merupakan bentuk memanjakan pelaku. ${ }^{107}$ Pemikiran tersebut lah yang mendorong munculnya gagasan/ide mengenai kesetaraan antara sanksi pidana dan sanksi tindakan, ${ }^{108}$ yang dikenal dengan istilah double track system. Ide double track ini tidak sepenuhnya memakai satu di antara sanksi pidana dan tindakan, di mana kedua sanksi tersebut ditempatkan secara setara/ berimbang. ${ }^{109}$ Ide double track ini selaras/sejalan dengan ide pembaruan hukum pidana nasional yang berlandaskan pada ide keseimbangan yang berlandaskan pada filsafat keadilan sosial menurut Pancasila. ${ }^{110}$

\footnotetext{
106 Yaris Adhial Fajrin dan Ach. Faisol Triwijaya, "Pencegahan Korupsi Pasca Putusan MK Nomor 71/PUU/XIV/2016 Melalui Pendekatan Kebijakan”, HUMANI (Hukum dan Masyarakat Madani), Vol. 9, No. 1 Mei, 2019, hal. 53-63.

107 M. Sholehuddin, Sistem Sanksi dalam ..., hal. 29.

108 Sudarto menggambarkan perbedaan antara sanksi pidana dan sanksi tindakan adalah sebagai berikut: pertama, Pidana dimaksukan sebagai pembalasan atau pengimbalan, sedangkan tindakan sebagai perlindungan masyarakat serta permbinaan dan perawatan si pelaku; kedua, Pidana untuk orang yang normal atau mampu bertanggung jawab, sedangkan yang tidak dapat bertanggung jawab atau tidak mempunyai kesalahan diberikan tindakan terhadapnya. Lihat: Dwidja Priyatno, Sistem Pelaksanaan Pidana ..., hal. 10-11.

109 Sebab kedua bentuk sanksi tersebut memiliki fungsi masingmasing yang sama-sama penting. Lihat: Ibid., hal. 28.

110 Lihat: M. Sholehuddin, Sistem Sanksi Dalam ..., hal. 112-113.
}

Mendasarkan pada filosofi keseimbangan tersebut maka kejahatan dipandang sebagai bentuk gangguan terhadap keseimbangan, keselarasan, dan keserasian (evenwichtstoring) dalam kehidupan masyarakat yang mengakibatkan kerusakan individual maupun masyarakat. Sehingga pemidanaan merupakan reaksi masyarakat yang bertujuan untuk memulihkan kembali rusaknya keseimbangan, keserasian, dan keselearasan sebagai akibat dari suatu tindak pidana. ${ }^{111}$ Ide double track system yang menjalankan tindakan dan sanksi pidana secara setara merupakan konsep dari hukum pidana modern yang berorientasi kepada daaddaader strafrecht, yang itu serasi pula dengan citacita pengejawantahan prinsip monodualistik berupa keseimbangan antara kepentingan pelaku, korban dan masyarakat melalui sarana hukum pidana.

Sanksi pidana dalam double track system merupakan perwujudan perlindungan bagi masyarakat, yang oleh von Feuerbach disebut sebagai prevensi umum. ${ }^{112}$ Sedangkan sanksi tindakan dalam double track system berfungsi sebagai prevensi khusus yaitu agar pelaku tidak mengulangi perbuatannya dikemudian hari melalui jalan perbaikan pada diri pelaku. ${ }^{113}$ Tujuan gagasan double track system tersebut juga tercermin di dalam Undang-undang Nomor 12 Tahun 1995 tentang Pemasyarakatan, yang menggambarkan secara politis maupun secara filosofis mengenai arah tujuan pemidanaan melalui sarana hukum pidana Indonesia yang berpedoman kepada Pancasila sebagai landasan idiil bangsa Indonesia. ${ }^{114}$

11 Dwidja Priyatno, Sistem Pelaksanaan Pidana ..., hal. 6.

112 Sanksi Pidana dalam hal ini difungsikan sebagai pengimbalan atas perbuatan jahat yang dilakukan, sehingga pencelaan terhadap perbuatan pelaku ditujukan untuk menjerakannya. Lihat: Eddy O.S Hiariej. Prinsipprinsip Hukum Pidana... Op.cit., hal. 33.

113 Sanksi tindakan ditujukan untuk mendidik pelaku agar menjadi lebih baik, melalui sarana rehabilitasi salah satunya. Sanksi tindakan juga memiliki keterkaitan dengan perlindungan masyarakat yang tercermin dari tujuan mengubah pelaku yang telah menjadi baik tidak melakukan kembali perbuatan di kemudian hari yang berdampak kepada masyarakat yang terlindungi dari potensi kerugian dikemudian hari.

114 Bagian Penjelasan Umum undang-undang pemasyarakatan, menyatakan bahwa: "Bagi negara Indonesia yang berdasarkan Pancasila, pemikiran-pemikiran baru mengenai fungsi pemidanaan yang tidak lagi sekedar penjeraan tetapi juga merupakan suatu usaha rehabilitasi dan reintegrasi sosial". 
C. Double Track System Pelaku Tindak Pidana yang Berlatar Belakang Homoseksualitas

Sebagaimana yang sudah diterangkan pada bagian sebelumnya, bahwa double track system merupakan sebuah makanisme pemidanaan yang mengedepankan prinsip kesetaraan/ keberimbangan antara sanksi pidana (sebagai upaya menjerakan/prevensi umum) dengan sanksi tindakan (sebagai upaya rehabilitatif pelaku). ${ }^{115}$ Selain itu, sanksi pidana (khususnya pemenjaraan) memiliki dampak negatif, tidak terkecuali jika dijatuhkan kepada pelaku tindak pidana yang memiliki latar belakang homoseksualitas, seperti dampak stigmatisasi dan prisonisasi. Selain itu, perlu diingat kembali bahwa tujuan pemidanaan dalam kerangka pembaruan hukum nasional mendorong pidana lebih ditujukan kepada perbaikan pelaku dan pengayoman masyarakat. Memperhatikan poin-poin tersebut maka tidak ada salahnya jika penulis mewacanakan sebuah konsep double track system yang diperuntukkan bagi pelaku tindak pidana yang memiliki latar belakang homoseksualitas.

Homoseksualitas pertama kali diteliti dari perspektif klinis oleh seorang psikiatri Jerman yaitu Carl Westphal tahun 1869.116

115 Perkembangan hukum pidana dan sistem pemidanaan saat ini telah berorientasi kepada pelaku dan perbuatan (daad-dader straafrecht), sehingga jenis sanksi yang ditetapkan tidak hanya meliputi sanksi pidana, tetapi juga sanksi tindakan yang relatif lebih bermuatan pendidikan dari pada penderitaan, atau bisa disebut pula dengan istilah individualisasi pidana. Karakteristik individualisasi pidana meliputi: pertama, Pertanggungjawaban (pidana) bersifat pribadi/perorangan (asas personal); kedua, Pidana hanya diberikan kepada orang yang bersalah (asas culpabilitas;'tiada pidana tanpa kesalahan'); ketiga, Pidana harus disesuaikan dengan karakteristik dan kondisi si pelaku, sehingga perlu ada kelonggaran/fleksibilitas bagi hakim dalam memilih sanksi pidana (jenis maupun berat ringannya sanksi) dan harus ada kemungkinan modifikasi pidana (perubahan/penyesuaian) dalam pelaksanaannya. Lihat: Yesmil Anwar dan Adang, Pembaruan Hukum Pidana ..., hal. 37.

116 Jordan Blair Woods, "LGBT Identity and Crime”, ..., hal. 682-683. Westphal mempublikasikan riset mengenai lakilaki feminim serta perempuan maskulin, yang memiliki rasa tertarik kepada sesama jenis (ia menyebutnya dengan istilah "contrary sexual feeling"). Kemudian riset tersebut
Baru pada tahun 1886, psikiater Richard von Krafft-Ebing melakukan sebuah penelitian yang monumental mengenai homoseksualitas dalam karyanya "Psychopathia Sexualis", yang menggambarkan "inversi seksual" (sebutan Krafft-Ebing untuk istilah homoseksualitas) sebagai ciri kepribadian individu. ${ }^{117} \mathrm{Krafft}$ Ebing mendefinisikan heteroseksualitas sebagai norma biologis dan mengklasifikasikan perilaku seksual yang tidak berkembang biak lebih lanjut (termasuk homoseksualitas) sebagai manifestasi dari kelainan patologis. ${ }^{118}$ Sehingga KrafftEbing berpendapat bahwa sanksi/hukuman bukanlah respon yang efektif dan tepat, di mana ia merekomendasikan beberapa intervensi nonhukuman untuk mengatasi homoseksualitas, seperti adat istiadat dan kebersihan seksual yang baik, serta hipnosis. ${ }^{19}$ Berikutnya adalah pendapat seorang psikiater forensik J. Paul De River yang berpendapat bahwa homoseksualitas ditangani melalui psikoterapi dan pendidikan. ${ }^{120}$

Penelitian tersebut sedikit banyak berpengaruh terhadap bentuk-bentuk intervensi non-hukuman, seperti "perawatan" yang digunakan untuk "menyembuhkan" homoseksualitas selama 1940-an hingga 1980an di Inggris diantaranya dengan sengatan listrik, pemberian apomorphine untuk menghasilkan mual, desensitisasi fobia yang diasumsikan dari lawan jenis, psychodrama, abreaksi, pengobatan estrogen untuk mengurangi libido,

diadopsi oleh Arrigo Tamassia (1878) dengan istilah "invirsione dell istinto sessuale" (insting seksual terbalik). Kemudian psikolog dan neurolog ternama Prancis bernama Jean Martin Charcot (1825-1993) memasukan homoseksualitas ke dalam kelompok "sexual perversions" atau penyimpangan-penyimpangan seksual dan termasuk gangguan jiwa. Charcot memandang homoseksual sebagai "degrading consequences of a weakning of morals in a vitited society." Lihat juga: A. Ayub, "Penyimpangan Orientasi Seksual (Kajian Psikologis dan Teologis)", Tasfiyah: Jurnal Pemikiran Islam, Vol. 1, No. 2, 2017, hal. 179-226.

117 Ia berpendapat bahwa kaum homoseksual tidak dapat mengubah arah atau ekspresi hasrat seksual mereka dan oleh karena itu harus ditangani secara terapeutik bukan secara menghukum. Lihat: Peter Conrad and Alison Angell, "Homosexuality and Remedicalization"..., hal. 32. 118 Jordan Blair Woods, "LGBT Identity and Crime" ..., hal. 682-683.

$119 \quad$ Ibid.

$120 \quad$ Ibid., hal. 689. 
dan terapi elektrokonvulsif. Tidak berbeda jauh, di Amerika Serikat "pengobatan" pun beragam seperti hipnosis, terapi kejut listrik, psikoanalisis, mandi air dingin, pengebirian, sterilisasi, pemotongan saraf pudik, dan lobotomi, yang digunakan hingga akhir tahun 1948. ${ }^{121}$ Contoh-contoh tindakan tersebut dipandang oleh penulis sebagai suatu yang melampaui batas, serta tidak memiliki dasar keefektifitasan dalam upaya menyembuhkan seorang homoseksual. Pendekatan-pendekatan psikologis maupun sosial-budaya maupun keagamaan tidak banyak digunakan, sehingga hal tersebut memicu penolakan dari kelompokkelompok LGBT disetiap momentum APA akan mengeluarkan rekomendasi DSM. ${ }^{122}$ Padahal medikalisasi homoseksual, menurut Krafft-Ebing, dimaksudkan sebagai bentuk perlindungan terhadap sanksi hukum yang menindas. ${ }^{123}$

Ketika "interaksionisme simbolik" popular di tahun 1950-an yang memunculkan kerangka sosiologis dalam mempelajari penyimpangan, maka homoseksualitas digambarkan sebagai bentuk penyimpangan seksual yang berakar pada penyebab lingkungan seperti: masyarakat, (2) keluarga, (3) kelompok sebaya, dan (4) gerakan sosial. ${ }^{124}$ Oleh sebab itu, NARTH membentuk hubungan strategis dengan keluarga konservatif dan organisasi keagamaan untuk mendukung adanya terapi konversi. ${ }^{125}$ Selain itu ada pula hasil riset dari

121 Sana Loue, "Case Studies in Society, Religion, And Bioethics" ..., hal. 22-23.

122 Jordan Blair Woods, "LGBT Identity and Crime" ..., hal. 701-702.

123 Meskipun praktik medis yang menindas masih muncul dalam upaya psikiatris untuk mengubah homoseksual menjadi heteroseksual. Medicalization (medikalisasi) merupakan proses di mana masalah non-medis menjadi didefinisikan dan diperlakukan sebagai masalah medis. Sehingga dalam memahami suatu masalah dengan menggunakan intervensi medis atau mengadopsi kerangka medis untuk mengobatinya. Lihat: Peter Conrad and Alison Angell, "Homosexuality and Remedicalization" ..., hal. 32 .

124 Jordan Blair Woods, "LGBT Identity and Crime” ..., hal. 693.

125 Peter Conrad and Alison Angell, "Homosexuality and Remedicalization”..., hal. 34.
Robert L. Spitzer tahun 2003, yang menunjukan keberhasilan perubahan orientasi seksual dari 200 orang yang menjalani terapi. ${ }^{126}$ Ada pula William Glasser, seorang psikiater, yang pada tahun 1965 mengemukakan mengenai "Reality therapy" sebagai salah satu bentuk terapi perilaku kognitif. Terapi tersebut merupakan salah satu bentuk modifikasi perilaku karena dalam aplikasi institusional merupakan jenis pengkondisian operatif yang tidak ketat yang keberhasilannya dalam menerjemahkan beberapa konsep modifikasi perilaku ke dalam model praktek yang relatif sederhana dan lugas. ${ }^{127}$ Selain reality therapy, ada pula SolutionFocused Therapy (SFT) yang dikembangkan oleh Brief Family Therapy Center, Milwaukee. SFT menggunakan pendekatan psikoterapi berdasarkan pembangunan solusi daripada pemecahan masalah, yang fokusnya adalah membantu klien mengidentifikasi dan memperkuat kekuatan dan sumber daya mereka menuju tujuan yang diinginkan oleh klien, melalui cara mengeksplorasi sumber daya saat ini dan harapan masa depan daripada masalah saat ini dan penyebab masa lalu. ${ }^{128}$

Menurut Dadang Hawari, homoseksual merupakan penyakit yang bisa diobati karena homoseksual tidak terjadi dengan sendirinya, namun karena melalui perkembangan psikoseksual terutama karena faktor keluarga dan pergaulan. ${ }^{129}$ Pengobatan dilakukan dengan mengubah lingkungan pergaulan sosial

126 Ayub "Penyimpangan Orientasi Seksual (Kajian Psikologis dan Teologis)" ..., hal. 198.

127 Untuk masalah homoseksual, pendekatan terapi realitas dapat diterapkan untuk membantu pendekatan masalah homoseksualitas. Reality therapy merupakan salah satu bentuk modifikasi tingkah laku dalam aplikasi institusionalnya yang merupakan jenis pengkondisian operatif yang tidak ketat. Alasan Glasser mendapatkan popularitas adalah keberhasilannya dalam menerjemahkan beberapa konsep modifikasi perilaku menjadi model praktik yang relatif sederhana dan langsung. Lihat: Alifa S. Ramadina dan Budi Astuti, "Reality Counseling Approach in Understanding Homosexual Awareness", Proceedings, the 2nd International Seminar on Guidance and Counseling 2019 (ISGC 2019), hal. 238.

128 Husmiati. "Working with Homosexual Clients: ...", hal. 14-16.

129 Ani Khairani dan Didin Saefudin, "Homoseksual berdasarkan pandangan Psikologi Islam ...”, hal. 134. 
yang menjadikan orang tersebut berperilaku yang demikian. Sebab pada prinsipnya seorang homoseksual secara fisik dan psikis pada prinsipnya tumbuh dan berkembang normal, tetapi karena lingkungan keluarga atau pergaulannya membentuk orientasi seksual seseorang menjadi homoseksual. Pengaruh tersebut semisal sering menonton video seks dengan adegan homoseksual atau yang bersangkutan pernah mendapat kekerasan seksual (sodomi). ${ }^{130}$ Memperhatikan adanya berbagai faktor tersebut, terdapat berbagai gagasan mengenai metode penyembuhan persoalan homoseksualitas (selaian apa yang sudah dipaparkan di atas). Misalnya, gagasan dari Khilman Rofi Azmi mengenai model dakwah kekinian untuk kaum homoseksual melalui teknik kontinum konseling berbasis Alquran, sebagai salah satu upaya menyadarkan orang-orang yang memiliki masalah mengenai homoseksualitas, melalui pendekatan spiritual keagamaan. ${ }^{131}$ Ada pula gagasan dari Humam Iqbal Azizi dalam skripsinya, mengenai terapi behavioristik untuk menyembuhkan orientasi seks menyimpang. ${ }^{132}$

Pemaparan mengenai berbagai macam riset di atas, menggambarkan bahwa mengenai persoalan homoseksualitas yang dialami oleh seseorang dapat dilakukan tindakan-tindakan perawatan/terapi. Sehingga ide double track system terhadap pelaku tindak pidana yang memiliki latar belakang homoseksualitas dapat dimungkinkan untuk diterapkan. Adapun tujuan memberikan sanksi tindakan tersebut adalah:

130 Dapat dikatakan penyebab sesorang menjadi homoseksual bukan karena alamiah atau genetic, tetapi terbentuk karena faktor-faktor dari luar diri yang bersangkutan Lihat: Fatimah Asyari. "LGBT dan Hukum Positif Indonesia" ..., hal. 59.

131 Khilman Rofi Azmi, "Model Dakwah Milenial untuk Homoseksual Melalui Teknik Kontinum Konseling Berbasis Alquran", Al-Balagh: Jurnal Dakwah dan Komunikasi, Vol. 4, No. 1, 2019, hal. 25-58.

132 Humam Iqbal Azizi, "Terapi Behavioristik untuk Menyembuhkan Orientasi Seks Menyimpang pada SSA (Same Sex Attraction) di Yayasan Peduli Sahabat Kota Tangerang Selatan (Analisis Fungsi Bimbingan Konseling Islam)", Skripsi Universitas Islam Negeri Walisongo Semarang, 2019, hal. 86. a. Mengembalikan pelaku menjadi orang normal pada umumnya, atau dengan kata lain menyembuhkannya dari persoalan homoseksualitas;

b. Menyadarkan perihal perbuatannya yang salah dan melanggar hukum, serta menumbuhkan dan membebaskan dari rasa bersalah;

c. Menyembuhkan pelaku jika memiliki penyakit seksual yang menular, atau paling tidak agar ia tidak menyebarkan penyakit tersebut;

d. Mengisolasi sementara waktu guna memberikan rasa aman terhadap masyarakat/korban;

e. Apabila tidak berhasil disembuhkan dari persoalan homoseksualitas, paling tidak dapat mengubah mainset pelaku untuk tidak menyebarkan, menghasut, atau mengajak orang lain untuk menjadi homoseksual; dan

f. Meresosialisasi dan mengintegrasi pelaku kembali ke masyarakat, sebagai pribadi yang telah berubah menjadi lebih baik dari sebelumnya.

Penerapan ide double track system ini, khususnya perihal sanksi tindakan, tidak serta merta dapat diberikan kepada pelaku kejahatan berlatar belakang homoseksualitas. Sebab sebagai seorang yang dinilai dapat bertanggung jawab dan dapat dibebani pertanggungjawaban pidana maka sejatinya ia merupakan orang yang secara kesadaran dapat melakukan kejahatan dalam bentuk dan jenis apapun, sehingga tidak menutup kemungkinan ia melakukan kejahatan yang dipandang berbahaya dan melampaui batas dan rasa kemanusiaan (sadistik). Memperhatikan kemungkinan itu, terhadap pelaku kejahatan yang memiliki ciri tersebut, diutamakan untuk diberikan sanksi pidana, bukan sanksi tindakan. Akan menjadi krusial peran dari pedoman pemidanaan sebagaimana yang tertuang di dalam RKUHP Nasional Pasal 54, dimana hakim maupun penegak hukum lainnya perlu memperhatikan hal-hal tersebut dalam menuntut maupun memutus perkara yang berlatar belakang homoseksualitas. 
Pasal 54 RKUHP Nasional merumuskan bahwa dalam pemidanaan, wajib dipertimbangkan beberapa hal, seperti, kesalahan pelaku tindak pidana; motif dan tujuan melakukan tindak pidana; sikap batin pelaku tindak pidana; tindak pidana dilakukan dengan direncanakan atau tidak direncanakan; cara melakukan tindak pidana; sikap dan tindakan pelaku sesudah melakukan tindak pidana; riwayat hidup, keadaan sosial, dan keadaan ekonomi pelaku tindak pidana; pengaruh pidana terhadap masa depan pelaku tindak pidana; pengaruh tindak pidana terhadap korban atau keluarga korban; pemaafan dari korban dan/atau keluarganya; dan/atau nilai hukum dan keadilan yang hidup dalam masyarakat. Kemudian lebih lanjut, Pasal 54 ayat (2) RKUHP Nasional merumuskan ringannya perbuatan, keadaan pribadi pelaku, atau keadaan pada waktu dilakukan Tindak Pidana dapat dijadikan dasar pertimbangan untuk tidak menjatuhkan pidana atau tidak mengenakan tindakan dengan mempertimbangkan segi keadilan dan kemanusiaan."

Mengenai layak atau tidaknya seorang pelaku kejahatan berlatar belakang homoseksualitas untuk dikenai tindakan rehabilitasi harus lah melalui pertimbangan ahli, baik dokter maupun psikiater/psikolog. Begitu juga mengenai tempat dan lamanya menjalani rehabilitasi, penegak hukum juga perlu mendengarkan pertimbangan dari ahliahli terkait terutama psikolog maupun psikiater. Selain itu, mengenai masa menjalani rehabilitasi dapat dihitung sama dengan masa menjalani pidana. Pertimbangan lainnya adalah terkait persoalan kapasitas lembaga pemasyarakatan, apakah mendukung/tidak dalam usaha merehabilitasi pelaku menjadi pribadi yang lebih baik. Penjabaran penulis tersebut mengenai limitasi antara sanksi tindakan dan sanksi pidana, merupakan ciri dari ide individualisasi pidana, dimana dalam memidana seorang pelaku kejahatan harus disesuaikan dengan karakteristik dan kondisinya, sehingga harus ada kelonggaran/fleksibilitas bagi hakim dalam memilih sanksi pidana (jenis maupun berat ringannya sanksi) dan harus ada kemungkinan modifikasi pidana (perubahan/penyesuaian) dalam pelaksanaannya.

Gagasan atau ide penulis mengenai double track system tersebut bukan tanpa hambatan. Terlebih lagi dalam RKUHP Nasional 2019 Pasal 108, tidak memasukkan persoalan homoseksualitas sebagai salah satu kualifikasi bagi seorang pelaku untuk diberikan tindakan rehabilitasi. Padahal secara teoritis double track system selaras dengan teori relatif (tujuan) pemidanaan, in casu pada contoh yang penulis berikan selain pidana yang dijatuhkan akan juga terjadi upaya perbaikan bagi pelaku yaitu tingkah laku menyimpang (homoseksual) dapat dihilangkan. Tidak menyertakan persoalan homoseksual sebagai salah satu bentuk penyimpangan perilaku yang dapat di rehabilitasi akan menimbulkan kekhawtiran semakin masifnya dampak-dampak negatif disebabkan perilaku menyimpang homoseksual. Demi menciptakan kesimbangan monodualistik dalam ranah pemidanaan, pelaksanaan double track system terhadap tindak pidana yang berlatarbelakang karena penyimpangan perilaku homoseksual adalah sebuah bentuk pelindungan bagi masyarakat disatu sisi dan perlindungan individu (penderita penyimpangan perilaku homoseksual) di lain sisi. Dengan penerapan double track system terhadap tindak pidana yang dilakukan oleh pelaku homoseksual, diharapkan dapat tercapai keseimbangan monodualistik sebagai orientasi pembaharuan hukum pidana nasional dapat tercapai dan terlaksana.

\section{Penutup}

\section{A. Simpulan}

Hukum pidana positif Indonesia saat ini tidak melarang perbuatan homoseksual. Namun dalam beberapa pasal dalam KUHP dan di beberapa undang-undang di luar KUHP, suatu perbuatan dikategorikan sebagai tindak pidana karena memiliki keterkaitan dengan homoseksual. Pelarangan perbuatan yang berkaitan dengan homoseksual pada beberapa peraturan tersebut karena menekankan kepada akibat sebagai akibat homoseksual. Homoseksual tidak serta 
merta dapat dicela apabila tidak menimbulkan akibat atau tidak berbarengan dengan perbuatan lainnya. Hal ini tentunya merupakan ketidak sesuaian antara hukum pidana dengan ideologi bangsa yaitu Pancasila karena homoseksual dalam perspektif Pancasila adalah perbuatan tercela. Dengan demikian maka diperlukan solusi terhadap permasalahan tersebut.

Penerapan double track system bagi pelaku tindak pidana berlatar belakang homoseksual dirasa cukup relevan untuk diterapkan. Relevansi diterapkannya double track system didasarkan kepada perkembangan hukum pidana yang berorientasi korektif, rehabilitatif, dan restoratif yang bertujuan humanisasi hukum pidana. Seorang homoseksual bisa menjalani sanksi tindakan mengingat homoseksual masih bisa disembuhkan. Tentunya hal tersebut sejalan dengan orientasi pembaruan hukum pidana Indonesia serta hal ini sebagai upaya menghadirkan hukum pidana yang lebih bermanfaat di masa mendatang. Pemberlakuan double track system bagi pelaku tindak pidana berlatar belakang homoseksual merupakan ikhtiar menekan angka homoseksual yang tidak sesuai dengan Pancasila.

\section{B. Saran}

Hukum pidana yang berlaku saat ini (ius constituendum) dirasa tidak mencerminkan hukum yang humanis. Kajian double track system bagi pelaku tindak pidana berlatarbelakang homoseksual dirasa mampu menghadirkan hukum pidana yang mampu memanusiakan manusia. Dengan demikian berdasar hasil penelitian ini Pemerintah dan legislatif sebagai lembaga yang diberikan wewenang untuk melakukan pembentukan peraturan perundangundangan secepatnya untuk memikirkan kemungkinan menerapkanide double tracksystem dalam sistem pemidanaan Indonesia. Penerapan double track system tersebut dikhususkan bagi orang yang melakukan kejahatan berlatar belakang homoseksual. Gagasan tersebut juga untuk mengejawantahkan pembaharuan hukum pidana yang telah lama dinantikan oleh masyarakat Indonesia.

\section{Daftar Pustaka}

\section{Jurnal}

Andina, Elga. "Faktor Psikososial dalam Interaksi Masyarakat dengan Gerakan LGBT di Indonesia". Aspirasi. Vol. 7. No. 2. Desember 2016.

Asyari, Fatimah. "LGBT dan Hukum Positif Indonesia”, Jurnal LEGALITAS, Vol. 2. No. 2. Desember 2017.

Ayub. "Penyimpangan Orientasi Seksual (Kajian Psikologis dan Teologis)", Tasfiyah: Jurnal Pemikiran Islam. Vol. 1. No. 2, 2017.

Azmi, Khilman Rofi. "Model Dakwah Milenial untuk Homoseksual Melalui Teknik Kontinum Konseling Berbasis Alquran”. Al-Balagh: Jurnal Dakwah dan Komunikasi. Vol. 4. No. 1. 2019.

B., Erlina. "Pengaruh Globalisasi Terhadap Perkembangan Hak Asasi Manusia Bidang Ekonomi, Sosial, Budaya (HESB) di Indonesia". Pranata Hukum. Vol. 6. No. 2. Juli 2011.

Bo'a, Fais Yonas. "Pancasila sebagai Sumber Hukum dalam Sistem Hukum Nasional". Jurnal Konstitusi, Vol.15. No. 1. 2018.

Conrad, Peter dan Alison Angell. "Homosexuality and Remedicalization". Society. Vol. 41 No. 5. 2004.

Djanggih, Hardianto dan Nurul Qamar. "Penerapan Teori-Teori Kriminologi dalam Penanggulangan Kejahatan Siber (Cyber Crime)". Pandecta, Vol. 13. No. 1. Juni 2018.

Fajrin, Yaris Adhial dan Ach. Faisol Triwijaya. "Pencegahan Korupsi Pasca Putusan MK Nomor 71/PUU/XIV/2016 Melalui Pendekatan Kebijakan". HUMANI (Hukum dan Masyarakat Madani). Vol. 9. No. 1. Mei 2019.

Hadisuprapto, Paulus. "Studi Tentang Makna Penyimpangan perilaku di Kalangan Remaja”. Jurnal Kriminologi Indonesia. Vol. 3. No. III. September 2004. 
Harahap, Indra Tua Hasangapon. Iqbal Kamalludin, Nila Arzaqi. "Kebijakan Hukum Pidana dalam Upaya Menanggulangi LGBT (Lesbian, Biseksual, dan Transgender) Berbasis Pancasila". Masalah-Masalah Hukum, Vol. 47. No.4. Oktober 2018.

Husmiati. "Working with Homosexual Clients: Application of Solution-Focused Therapy". Jurnal Psikologi Undip. Vol. 11. No.1. April 2012.

Jaya, Belardo Mega dan Muhammad Rusli Arafat. "Universalism Vs. Cultural Relativism dan Implementasinya dalam Hak Kebebasan Beragama di Indonesia". Pena Justisia: Media Komunikasi dan Kajian Hukum. Vol. 17. No. 2. 2017.

Kabir, Syahrul Fauzul. "Kejahatan dan Hukuman:

Tantangan Filosofis Determinisme-Kausal Terhadap Pertanggungjawaban Pidana”. Jurnal Hukum Ë Pembangunan, Vol. 49. No. 2. 2019.

Khairani, Ani dan Didin Saefudin, "Homoseksual Berdasarkan Pandangan Psikologi Islam”. Jurnal Ta'dibuna. Vol. 7. No. 2. Oktober 2018.

Khairani, Ani. "Pandangan Konselor tentang Homoseksual”, Ta'dibuna. Vol. 8. No.1. 2019.

Kirom, Syahrul. "Filsafat Ilmu Dan Arah Pengembangan Pancasila: Relevansinya dalam Mengatasi Persoalan Kebangsaan". Jurnal Filsafat. Vol.21. No. 2. 2011.

Luthan, Salman. "Dialektika Hukum dan Moral dalam Perspektif Filsafat Hukum". Jurnal Hukum Ius Quia Iustum. No. 4. Vol. 19. 2012.

Mansur, Syafi'in. "Homoseksual dalam Perspektif Agama-Agama di Indonesia". Jurnal Aqlania. Vol. 08. No. 01. 2017.

Mulyadi, Lilik. "Eksistensi Hukum Pidana Adat di Indonesia: Pengkajian Asas, Norma, Teori, Praktik, dan Prosedurnya”. Jurnal Hukum dan Peradilan. Vol. 2. No. 2. 2013.
Sulistyawan, Aditya Yuli. "Membangun Model Hukum yang Memerhatikan Kebutuhan Seksual Narapidana di Lembaga Pemasyarakatan: Telaah Paradigma Konstruktivisme". Jurnal Ilmu Hukum. Vol. 4. No. 1. 2014.

Tabiri, Michael Owusu. "Same-Sex Marriage: Secular and Religious Views". Journal of Educational System, Vol. 3. No. 11. 2019.

Triputra, Yuli Asmara. "Implementasi NilaiNilai Hak Asasi Manusia Global ke dalam Sistem Hukum Indonesia yang Berlandaskan Pancasila”. Jurnal Hukum Ius Quia Iustum. No. 2. Vol. 24. April 2017.

Turel, Susan C. "A Descriptive Analysis of Same-Sex Relationship Violence for a Diverse Sample". Journal of Family Violence. Vol. 15. No. 3. 2000.

Widayati, Lidya Suryani. "Kebijakan Kriminalisasi Kesusilaan dalam Rancangan Undang-undang tentang Hukum Pidana dari Perspektif Moral". Negara Hukum, Vol 9. No.2. 2018.

Wilujeng, Sri Rahayu. "Hak Asasi Manusia: Tinjauan dari Aspek Historis dan Yuridis". Humanika. Vol. 18. No.2. Juli 2013.

Woods, Jordan Blair. "LGBT Identity and Crime”. California Law Review, Vol. 105. No. 3. 2017.

Yansyah, Roby dan Rahayu, "Globalisasi Lesbian, Gay, Biseksual, dan Transgender (LGBT): Perspektif HAM dan Agama dalam Lingkup Hukum di Indonesia”. Jurnal Law Reform. Vol. 14. No. 1. 2018.

Yuliarso, Kunto Kurniawan dan Nunung Prajarto. "Hak Asasi Manusia (HAM) di Indonesia: Menuju Democratic Governance". Jurnal Ilmu Sosial Eु llmu Politik, Vol. 8. No. 3. Maret 2005.

Yusinta, Gallo Ajeng dan Dewi, Endang Sri Indrawati. "Pengalaman Menjadi Gay (Studi Fenomenologi pada Pria Homoseksual menuju Coming Out)". Jurnal Empati. Vol. 7. No. 3. Agustus 2017. 


\section{Buku}

Anwar, Yesmil dan Adang. Pembaruan Hukum Pidana, Reformasi Hukum. Jakarta: Penerbit PT Grasindo. 2008.

Arief, Barda Nawawi. Bunga Rampai Kebijakan Hukum Pidana. Jakarta: Kencana Prenada. 2008.

Bennett, Linda Rae. et.al Seksualitas di Indonesia; Politik Seksual, Kesehatan, Keberagaman, dan Representasi. Jakarta: Yayasan Pustaka Obor Indonesia. 2018.

Brook, Kelly. Education of Sexuality for Teenager. North Carolina. Charm Press. 2001.

Chazawi, Adami. Tindak Pidana Pornografi: Penyerangan Terhadap Kepentingan Hukum Mengenai Tegaknya Tatanan Kehidupan Akhlak dan Moral Kesusilaan Yang Menjunjung Tinggi Nilai-nilai Ketuhanan Yang Maha Esa dan Kemanusiaan Yang Adil dan Beradab, Surabaya: CV Putra Media Nusantara. 2009.

Hiariej Eddy O.S., Prinsip-prinsip Hukum Pidana. Yogyakarta: Cahaya Atama Pustaka $\geq$ 2014.

Knight Charlotte dan Kath Wilson. Lesbian, Gay, Bisexual and Trans People (LGBT) and The Criminal Justice System. London: Palgrave Macmillan. 2016

Loue, Sana. Case Studies in Society, Religion, And Bioethics. Cham: Springer. 2020.

M. Sholehuddin. Sistem Sanksi Dalam Hukum Pidana (Ide Dasar Double Track System dan Implementasinya). Jakarta: PT. Raja Grafindo Persada. 2003.

Muladi dan Barda Nawawi Arief. Teori-teori dan Kebijakan Pidana. Bandung: Alumni. 2010.

Priyatno, Dwidja. Sistem Pelaksanaan Pidana Penjara di Indonesia. Bandung: PT Refika Aditama. 2006.

Patterson, Dennis (editor/s). A Companion to Philosophy of Law and Legal Theory 2nd ed. Oxford: Wiley-Blackwell. 2010.
Santoso, Topo dan Eva Achjani Zulfa. Kriminologi. Jakarta: Rajawali Press. 2014.

Soesilo, R., Kitab Undang-Undang Hukum Pidana (KUHP) serta Komentar-Komentarnya Lengkap Pasal Demi Pasal. Bogor: Politea. 1995.

\section{Lain-lain}

Pusat Penelitian Kesehatan Universitas Indonesia, Laporan kajian pandangan tokoh agama dan tokoh masyarakat terhadap lesbian, gay, biseksual, dan transgender (LGBT) di Jakarta, Bogor, Depok, dan Tangerang, 2015. Kementerian Pemberdayaan Perempuan dan Anak.

Ramadina, Alifa S. dan Budi Astuti. "Reality Counseling Approach in Understanding Homosexual Awareness". Proceedings. the 2nd International Seminar on Guidance and Counseling 2019 (ISGC 2019).

Azizi, Humam Iqbal. "Terapi Behavioristik Untuk Menyembuhkan Orientasi Seks Menyimpang Pada SSA (Same Sex Attraction) di Yayasan Peduli Sahabat Kota Tangerang Selatan (Analisis Fungsi Bimbingan Konseling Islam)". Skripsi Universitas Islam Negeri Walisongo Semarang, 2019.

\section{Pustaka Dalam Jaringan}

BBC News 4 April 2019 "Selain Brunei, Negara Mana Saja yang Berlakukan Hukuman Mati bagi LGBT?" https://www.bbc.com/ indonesia/majalah-47796268. diakses tanggal 22 Desember 2019.

Firmansyah, Teguh. 31 Mei 2016. Ini Kronologi Pembunuhan Pasangan Sejenis di Bogor. https://www.republika.co.id/berita/ nasional/daerah/16/05/31/o81ghn377-inikronologi-pembunuhan-pasangan-sejenisdi-bogor. diakses tanggal 27 Maret 2020.

Gune, Edy. 22 Februari 2016, Astaga, 25 Kasus Pembunuhan ini Berlatar Nafsu Sejenis. https://www.kompasiana.com/edygune/ 56cadd1d317a61160f49154e/astaga-25kasus-pembunuhan-ini-berlatar-nafsusejenis? page $=$ all. diakses tanggal 16 April 2020 
Indo, Benni. 9 Mei 2018, Tiga Bocah di Nurdin, Endang dan Mohamad Susilo Malang Jadi Korban Sodomi, saat 11 Januari 2020. "Reynhard Sinaga: Terungkap, Pekerjaan Pria Pelakunya Mengejutkan. https://surabaya.tribunnews. com/2018/05/09/tiga-bocah-di-malangjadi-korban-sodomi-saat-terungkappekerjaan-pria-pelakunya-mengejutkan. diakses tanggal 15 April 2020.

Irnanda, "Terpaksa Menjadi Gay di Balik Jeruji Besi". https://news.detik.com/ video/190725027/terpaksa-menjadi-gaydi-balik-jeruji-besi. diakses tanggal $30 \mathrm{Juli}$ 2019. 